Federal Reserve Bank of Minneapolis

Research Department Staff Report 270

June 2000

\title{
Re-Examining the Contributions of Money and Banking Shocks to the U.S. Great Depression*
}

\author{
Harold L. Cole \\ Federal Reserve Bank of Minneapolis
}

Lee E. Ohanian

Federal Reserve Bank of Minneapolis and U.C.L.A.

\begin{abstract}
This paper quantitatively evaluates the hypothesis that deflation can account for much of the Great Depression (1929-33). We examine two popular explanations of the Depression: (1) The "high wage" story, according to which deflation, combined with imperfectly flexible wages, raised real wages and reduced employment and output. (2) The "bank failure" story, according to which deflationary money shocks contributed to bank failures and to a reduction in the efficiency of financial intermediation, which in turn reduced lending and output. We evaluate these stories using general equilibrium business cycle models, and find that wage shocks and banking shocks account for a small fraction of the Great Depression. We also find that some other predictions of the theories are at variance with the data.
\end{abstract}

*This paper is forthcoming in the NBER Macro Annual 2000. We thank Andy Atkeson, Ben Bernanke, Narayana Kocherlakota, Ken Rogoff, Art Rolnick, and our discussants Michael Bordo and Mark Gertler for helpful comments. We thank Daniel Hammermesh for CPS wage data and Jonathon Parker for estimates of compositional wage changes. Special thanks go to Ed Prescott for many discussions about the Great Depression. We have also benefited from the outstanding research assistance of Jesus Fernandez-Villaverde. The views expressed herein are those of the authors and not necessarily those of the Federal Reserve Bank of Minneapolis or the Federal Reserve System. 


\section{Introduction}

Many economists argue that deflation can account for much of the Great Depression (1929-33) in the United States. According to this story, a sharp decline in the money supply caused rapid deflation, which in turn reduced output. Empirical research has documented large decreases in money, prices, and output between 1929-33. But there is much less work assessing whether this shock can plausibly account for the Depression within fully articulated general equilibrium models. This paper quantitatively evaluates the deflation hypothesis with dynamic, general equilibrium business cycle models.

Evaluating the deflation hypothesis with general equilibrium models requires an explicit theory of why deflation reduced output so much in the 1930s. Since there are several explanations for this in the literature, we first narrow the field by requiring that any successful deflation theory of the Depression also be consistent with macroeconomic activity during other major deflations. We therefore determine which deflation theories satisfy this criterion by comparing the Great Depression to macroeconomic activity during the early 1920s, which is a period of comparable deflation, but a much less severe downturn in economic activity.

We find that two of the four most popular explanations are ruled out by this consistency criterion. These are the "surprise deflation story" of Lucas and Rapping (1969), which argues that the Great Depression was severe because the deflation was unexpected, and the "debtdeflation" story of Irving Fisher, which argues that the Great Depression was severe because deflation substantially raised the real value of private debt. The two stories that are not ruled out are the "high wage story" and the "banking story." According to the high wage story, deflation, combined with imperfectly flexible wages, raised real wages and reduced employment and output. A number of economists report evidence in favor of this story, including Eichengreen and Sachs (1985), Bernanke and Carey (1996), and Bordo, Erceg, and Evans (2000). According to the bank failure story, deflationary money shocks contributed to bank failures and to a reduction in the efficiency of financial intermediation, which in turn reduced lending and output. Bernanke (1983) reports evidence in favor of this story.

Following this empirical analysis, we develop two general equilibrium models to separately evaluate the wage shock hypothesis and the banking shock hypothesis. We ask two questions: Can these shocks drive down output per adult nearly 40 percent relative to trend 
between 1929-33? Are the other predictions of the theories consistent with the data?

Our main finding is that wage shocks and banking shocks account for a small fraction of the Great Depression. We also find that some other predictions of the theories are at variance with the data. We conclude that these results raise questions about the deflation and banking hypothesis as an explanation of the Great Depression in the United States.

The paper is organized as follows. Section 2 presents the comparison between the Great Depression and the 1921-22 depression, and the evaluation of the four popular deflation stories for the Great Depression. We then go on to develop general equilibrium models for the two stories that are not ruled out by this comparison - the high wage story and the banking story. Section 3 presents a general equilibrium model with above-market wages, and also presents a quantitative assessment of the wage hypothesis. Section 4 presents a general equilibrium model with an intermediation sector to assess the macroeconomic impact of bank failures. Since our results support neither the wage nor banking story, section 5 briefly discuss two other possible contributing factors to the Great Depression: changes in asset prices and changes in productivity. Section 6 presents a summary and conclusion.

\section{An Empirical Puzzle about the Deflation Hypothesis}

A successful theory of the Great Depression based on deflation should account for macroeconomic activity during 1929-33 and should also be consistent with macroeconomic activity during other major deflations. This section empirically evaluates this consistency requirement by comparing changes in prices and real output during 1929-33 to those during a period of comparable deflation: 1920-22.

Table 1 shows the percentage change in the GNP deflator, real GNP, real consumption, and real investment during these two episodes. The three quantity variables are deflated by their specific deflators, are measured relative to the adult (16 and over) population, and are detrended. ${ }^{1}$ Deflation is similar during these two periods: the price level fell about 20 percent between 1920-22, and also fell about 20 percent between 1929-32. Despite these

\footnotetext{
${ }^{1}$ We detrended these three quantity variables at a rate of 1.9 percent per year. We define this rate as normal growth, because it is the growth rate of output/adult both before the Great Depression (1919-1929), and after WWII (1947-1997), and because it is close to the 2 percent average growth rate between 1900-1997. It is also worth noting that output/adult in 1929 is very close to an OLS trend line fit to this series between 1900-1997. This suggests that output was close to its normal trend value in 1929.
} 
similar deflations, however, output fell much more between 1929-32 than between 1920-22. Real GNP fell 36 percent between 1929-32, but just 4 percent between 1920-22.

These data raise a puzzle about the deflation hypothesis: If the 20 percent deflation of the 1930s caused the Great Depression, why didn't the 20 percent deflation of the 1920s also cause a major depression? Resolving this puzzle requires finding some other shock(s) that magnify the depressing effects of deflation and that were present in the 1930s, but not in the 1920s. There are a several stories for why the 1930s deflation had such large, negative real effects. But can these stories explain why the Great Depression was so much worse than the 1921-22 Depression? We address this question in the next section.

\section{Table 1: Deflation and Output - Output and its Components ${ }^{2}$}

\begin{tabular}{|l|l|l|l|l||l|l|l|l|l|}
\hline \multicolumn{3}{|c||}{ Depression of 1921-22 $(1920=100)$} & \multicolumn{3}{|c|}{ The Great Depression $(1929=100)$} \\
\hline Year & P & Y & C & Fixed I & Year & P & Y & C & Fixed I \\
\hline 1921 & 85.2 & 93.9 & 102.4 & 86.1 & 1930 & 97.5 & 86.9 & 90.0 & 73.2 \\
\hline 1922 & 80.6 & 96.2 & 102.7 & 114.4 & 1931 & 88.5 & 77.6 & 84.3 & 48.5 \\
\hline
\end{tabular}

\section{A. Can the Standard Stories Explain the Severity of the Great Depression?}

Four popular deflation stories for the Great Depression are: (1) the deflation was unexpected, (2) nominal debt levels were high, (3) nominal wages were imperfectly flexible, and (4) there were many bank failures in addition to the deflation. We consider each of these stories in turn and ask whether they might be consistent with both the Great Depression and the 1921-22 Depression. For each story, this consistency requires that the shock that magnified the real effect of deflation in the 1930s not be present in the 1920s.

\footnotetext{
${ }^{2}$ The price level is from Romer (1988) for 1921-23, and from Historical Statistics for 1929-33. The output data for 1920-22 are from Kendrick (1961), p. 294. Romer (1988) argues that the Kendrick series is a better output measure for the 1920s than the Commerce Depatment measure, which is based on preliminary work of Kuznets and Kendrick. The output data for 1929-1933 are from the NIPA. The population data is from Historical Statistics, p. 10.
} 


\section{Differences in Deflation Predictability Between the 1920s and 1930 s}

Some theories predict that only unanticipated deflation depresses real economic activity. Lucas and Rapping (1969) argue that the 1930s deflation was unexpected and that this was an important factor behind the severity of the Great Depression. Can differences in the predictability of the 1920s and 1930s deflations explain the difference in the severity of these two depressions? We address this question by comparing nominal and ex post real interest rates between these two periods. ${ }^{3}$ If differences in the predictability of deflation can explain both the Great Depression and the Depression of 1921-22, we should observe very low nominal interest rates in the 1920s, but relatively high nominal and ex-post real interest rates during the 1930s.

Table 2: Nominal and Ex-Post Real Interest Rates: 1920s and 1930s ${ }^{4}$

\begin{tabular}{|l|l|l|l||l|l|l|l|l|}
\hline & \multicolumn{3}{|c||}{ Depression of 1921-22 } & \multicolumn{4}{c|}{ The Great Depression } \\
\hline Years & 1921 & 1922 & Avg. & 1930 & 1931 & 1932 & 1933 & Avg. \\
\hline Treasury Notes - Nominal & 4.83 & 3.47 & $\mathbf{4 . 3 5}$ & 2.23 & 1.15 & 0.78 & 0.26 & $\mathbf{1 . 1 0}$ \\
\hline Treasure Notes - Real & 19.63 & 8.87 & $\mathbf{1 4 . 2 5}$ & 4.73 & 10.38 & 10.95 & 2.78 & $\mathbf{7 . 2 1}$ \\
\hline
\end{tabular}

Table 2 shows average annual nominal and real interest rates on 3 to 6 month U.S. Treasury Notes and Certificates. The real rate is the nominal rate minus the percentage change in the annual GNP deflator. The most striking feature of these data is that both nominal and real interest rates are higher during the Depression of 1921-22. The average nominal rate on Treasury securities is 4.35 percent between 1921-22 compared to an average of 1.1 percent between 1930-33. The average real rate on these securities is 14.25 percent between 1921-22, compared to an average of 7.21 percent between 1930-30. ${ }^{5}$ These data suggest that the 1930s deflation was more predictable than the 1920s deflation, rather than

\footnotetext{
${ }^{3}$ There is some work addressing the predictability of the 1930s deflation (see Hamilton (1992) and Cecchetti (1992)), but we are unaware of any studies of the predictability of the deflation of the early 1920s, or any comparison of the predictability of deflation between the two periods.

${ }^{4}$ The data are from the Federal Reserve Board (1943). The results are very similar using 4-6 month prime commercial paper.

${ }^{5}$ It may seem surprising that the deflation of the early 1920s was more unexpected, since monetary policy after wars traditionally produced deflation. However, the timing and rates of these deflations were probably much less certain.
} 
less predictable. We conclude from these data that unexpected deflation is not the key factor behind the relative severity of the Great Depression. ${ }^{6}$

\section{Differences in Private Debt-Deflation Between the 1920s and 1930s}

Irving Fisher (1933) suggested that deflation and high private debt levels contributed to the Great Depression by reducing borrower wealth and constraining lending. This is known as the "debt-deflation" view of the Great Depression. Before asking whether this story is consistent with both depressions, it is important to note that there are two separate macroeconomic effects from this redistribution. We call one the debt burden effect of debtdeflation, which is Fisher's original view. The other is the wealth transfer effect, in which unexpected deflation transfers wealth from debtors to creditors. On average, creditors are older and borrowers are younger. This transfer increases the old generation's consumption, but changes their labor input little in absolute terms since their labor endowment is low. The wealth transfer will tend to increase the hours of the young generation. Overall, the wealth transfer effect should increase aggregate hours and output and thus will tend to offset the debt burden effect. Thus, there is no theoretical presumption that wealth redistributions between debtors and creditors reduce aggregate employment and output.

If the "debt-deflation" story can explain the severity of the Great Depression, the debt burden effect must be quantitatively much more important in the 1930s than in the 1920s. Two factors that affect the quantitative impact of the debt burden effect are the size of the stock of debt at the start of the deflation and the pattern of deflation. A larger initial stock of debt and a rapid deflation will tend to increase the debt burden effect. We measure the increase in the debt burden as the increase in the real value of debt (relative to output) due to deflation over the first two years of each depression.

Table 3 shows the initial stock of debt relative to output at the price level peak prior to each depression, as well as the percentage change in prices in the first two years of each depression, the implied percentage increase in the debt burden relative to initial output, and the percentage change in real output. The most striking feature of these data is that the

\footnotetext{
${ }^{6}$ Some economists have also suggested that high real interest rates were an important contributing factor to the Great Depression. The fact that real interest rates were substantially higher during the 1921-22 Depression casts doubt on this explanation.
} 
debt burden channel rises more in 1921-22 than in 1929-31. The more rapid 1920s deflation increased the debt burden by 0.29 between 1920-22, compared to 0.20 between 1929-31. This higher debt burden increase, however, is associated with a much smaller decrease in output. Real GNP fells 3.8 percent between 1920-22, but fells 22.4 percent between 1929-31.

Table 3: Increase in the Private Debt Burden Due to Deflation: The Depression of 1921-22 vs. the Great Depression ${ }^{7}$

\begin{tabular}{|l|l|l|l|l|}
\hline Year & $\begin{array}{l}\text { Private Debt } \\
\text { Relative to } \\
\text { Output }\end{array}$ & $\begin{array}{l}\text { in First 2 Years } \\
\text { of Deflation }\end{array}$ & $\begin{array}{l}\text { in First 2 Years } \\
\text { of Deflation }\end{array}$ & $\begin{array}{l}\% \triangle \text { in GNP } \\
\text { in First 2 Years } \\
\text { of Deflation }\end{array}$ \\
\hline 1920 & 1.20 & $-19.4 \%$ & .29 & $-3.8 \%$ \\
\hline 1929 & 1.56 & $-11.5 \%$ & .20 & $-22.4 \%$ \\
\hline
\end{tabular}

Explaining the severity of the Great Depression through debt-deflation thus requires a model in which an initial debt stock of 1.2, with 19 percent deflation, is associated with only a 4 percent decrease in output, while an initial debt stock of 1.56, with 11 percent deflation, drives down output by more than 22 percent. ${ }^{8}$ We are unaware of any quantitatively plausible model that is consistent with these observations. We conclude from these data that the

${ }^{7}$ The increase in the debt burden is given by

$$
\frac{100 * D / Y}{100+\% \triangle P}-D / Y
$$

where $D$ is the debt-to-output ratio.

There are two basic sources of data on business liabilities in the Historical Statistics. The first is the nominal debt series put out by the BEA, which we have used. The second is from IRS data on corporate tax returns (see series V 108-140). The IRS data only begins in 1926, and there appears to be a significant difference as to the indicated increase in corporate debt levels between the two sources. The IRS data indicate that corporate debt in the form of bonded debt and mortgages rose $47 \%$ between 1926 and 1929 . This figure seems too large and suggests that the coverage level was initially low when the IRS was first collecting the returns data. This view is supported by the observation that according to the IRS data the total debt of the corporate sector - including notes, accounts payable, bonded debt and mortgages - was only $\$ 55.8$ billion in 1926, while the net debt from the BEA for the total corporate sector in 1926 was $\$ 76.2$ billion.

${ }^{8}$ Olney (1999) argues that high consumer debt levels and extreme default penalties help account for the large drop in consumption in 1930. If this indebtedness was key, we would expect a larger than normal decrease in consumer durables spending in 1930. However, the decrease in the ratio of durables to output in 1930 is small relative to postwar recessions. The major decrease in consumption in 1930 is due to nondurables and services. 
debt-deflation story does not explain why the Great Depression was worse than the 1921-22 Depression. ${ }^{9}$

\section{Differences in Wages Between the 1920s and 1930s}

Some economists believe that wage changes increased the depressing effects of deflation in the 1930s. Before addressing whether differences in wages can explain the difference between the Great Depression and the Depression of 1921-22, it is important to recognize that there is disagreement over how wage changes may have contributed to the Great Depression. Some economists, for example Lucas and Rapping (1972), and Lucas (1983), argue that the Great Depression was severe because nominal wages fell so much. Others, for example Bernanke and Carey (1996), Bordo, Erceg, and Evans (2000), and Eichengreen and Sachs (1985), argue that the Great Depression was severe because nominal wages were imperfectly flexible and did not fall enough.

Since the Lucas-Rapping view is based on unexpected deflation, and it is unlikely that unexpected deflation is responsible for the severity of the Great Depression, we focus on the inflexible wage hypothesis. According to this hypothesis, inflexible nominal wages, combined with deflation, raised real wages which reduced employment and output.

Explaining the relative severity of the Great Depression through high wages requires: (1) real wages well above trend in the 1930s, and significantly higher than wages in1921-22, and (2) a theory of labor market failure during the 1930s - if the Great Depression was caused by high real wages, there would have been enormous competitive pressure for wages to fall.

We begin by examining wages between the two Depressions. Unfortunately, there is limited survey wage data that is both of reasonable quality and is consistently available during both the 1920s and 1930s. Two sectors for which such data are available are agriculture and manufacturing. Tables 4 and 5 show that detrended wage changes are fairly similar between the two episodes and that wage changes differed significantly across sectors of the economy. Some real wages fell substantially during both depressions, while others remained near trend. The wage in the farm sector is an example of one real wage that fell significantly during both

\footnotetext{
${ }^{9}$ It is worth noting that the difference in debt levels between the two periods - 1.2 vs. 1.56 - may overstate the actual difference in the debt burden channel, since financial markets were probably more sophisticated in the 1930s, and as a consequence might have managed larger debt levels more efficiently.
} 
depressions. Table 4 shows that, on average, it is about 28 percent below trend during both periods.

Table 4: Farm Wages $^{10}$

\begin{tabular}{|l|l|l||l|l|l|l|}
\hline & \multicolumn{2}{|c||}{$\begin{array}{c}\text { Depression of 1921-22 } \\
(1920=100)\end{array}$} & \multicolumn{4}{c|}{ The Great Depression } \\
& \multicolumn{2}{|c||}{$(1929=100)$} \\
\hline Years & 1921 & 1922 & 1930 & 1931 & 1932 & 1933 \\
\hline Real Wage & 71.9 & 73.1 & 93.0 & 76.8 & 64.7 & 60.2 \\
\hline
\end{tabular}

Table 5: Manufacturing Average Hourly Earnings ${ }^{11}$

\begin{tabular}{|l|l|l||l|l|l|l|}
\hline & \multicolumn{2}{|c||}{$\begin{array}{c}\text { Depression of 1921-22 } \\
(1920=100)\end{array}$} & \multicolumn{4}{c|}{ The Great Depression } \\
& \multicolumn{2}{|c||}{$1929=100)$} \\
\hline Years & 1921 & 1922 & 1930 & 1931 & 1932 & 1933 \\
\hline Real Wage & 101.5 & 101.2 & 102.1 & 106.8 & 106.5 & 104.2 \\
\hline
\end{tabular}

In contrast, the real manufacturing wage rose modestly during the Great Depression and remained near trend in 1921-22. Table 5 shows the manufacturing wage during these two depressions. The basic data for the Great Depression are from surveys conducted by the National Industrial Conference Board, and are considered to be among the best wage measures during the Great Depression. ${ }^{12}$ The real manufacturing wage, on average, was roughly 5 percent above trend during 1930-33 and about 1 percent above trend during the Depression of 1921-22.

\footnotetext{
${ }^{10}$ Source: Historical Statistics, p. 468. The farm wage rate is the daily wage without room and board. It is deflated by the GNP deflator and is detrended at 1.4 percent per year, as this is the average growth rate of real hourly compensation between 1947 and 1997.

${ }^{11}$ These data are deflated by the GNP deflator. We detrended manufacturing wages at a 1.4 percent annual rate, as this is the average growth rate of real hourly compensation between 1947 and 1997. The average growth rate of real manufacturing wages between 1923 and 1929 was slightly higher at 1.6 percent per year.

${ }^{12}$ The 1930s data are from Hanes (1996). The 1920s data is from the National Industrial Conference Board, and include average hourly earnings of all wage earners in 25 industries plus anthracite mining, railroads, and building trades. Industries include metal, textiles, leather, paper, furniture, lumber, meat, rubber. The data are on page 25 , table 2 .
} 
These manufacturing wage differences between the 1920s and 1930s do not seem large enough to account for the relative severity of the Great Depression. But without a formal model we do not know how much of the Great Depression these differences can explain. We therefore construct a two-sector general equilibrium model in Section 3 to assess the quantitative contribution of high wages in some sectors to the Great Depression.

\section{Differences in Bank Closings Between the 1920s and 1930s}

Many banks either temporarily suspended operations or failed during the early 1930s. Bernanke's (1983) widely-cited work shows that the number of banks that either closed temporarily or failed is a significant predictor of output during the Great Depression. Bernanke's work has led a number of economists to conclude that bank closings were an important contributing factor to the Great Depression. For example, Christina Romer's (1993) survey of the Great Depression argues that these closing were responsible for much of the fall in output between 1930 and 1933. According to the bank closing hypothesis, bank suspensions and failures destroyed private information about borrowers, which in turn reduced the efficiency of financial intermediation (see Romer 1993).

Table 6: Behavior of Commercial Bank Deposits ${ }^{13}$

\begin{tabular}{|l|l|l||l|l|l|l|l|}
\hline & \multicolumn{2}{|c||}{$1921-22$ Depression } & \multicolumn{5}{c|}{ The Great Depression } \\
\hline Years & 1921 & 1922 & 1929 & 1930 & 1931 & 1932 & 1933 \\
\hline Suspended/Total & $0.5 \%$ & $0.3 \%$ & $0.4 \%$ & $1.7 \%$ & $4.3 \%$ & $2.0 \%$ & $11.0 \%$ \\
\hline Loss/Total & $0.2 \%$ & $0.1 \%$ & $0.1 \%$ & $0.5 \%$ & $0.8 \%$ & $0.4 \%$ & $1.3 \%$ \\
\hline Total/Output & 0.52 & 0.55 & 0.58 & 0.64 & 0.65 & 0.78 & 0.75 \\
\hline
\end{tabular}

Can bank closings explain the difference between the Great Depression and the 192122 Depression? Table 6 presents a comparison of bank closings in the 1920s and 1930s. Since the importance of a bank suspension or failure depends on the size of the bank, we measure bank closings not by the number of banks that closed, but rather by the fraction of deposits in banks that either suspended operations or failed. The table thus shows the fraction of

\footnotetext{
${ }^{13}$ Source: Banking and Monetary Statistics 1914-1941, Board of Governors.
} 
total deposits in commercial banks that either suspended operations or failed, and shows the fraction of total deposits lost by depositors. ${ }^{14}$

Bank suspensions and failures were higher during the Great Depression. About 0.5 percent of banks, measured by deposits, either suspended operations or failed during the Depression of 1921-22, and about 0.2 percent of total deposits was ultimately lost. In comparison, an average of 2.6 percent of banks either suspended operations or failed between 1930-32, and an average of 0.4 percent of total deposits were ultimately lost during that period. Both of these ratios rose significantly in 1933 when President Franklin Roosevelt declared a bank holiday. An explicit economic model is needed to determine the quantitative importance of these differences for the severity of the Great Depression. We develop a model for this purpose in Section 4.

The final data we present is the ratio of total commercial bank deposits to output during these two depressions. This ratio rises significantly during the Great Depression. We present this data because it will be a key ratio in the model that we develop for assessing the macroeconomic impact of bank closings.

\section{B. Summary}

This section assessed whether four popular deflation stories for the Great Depression can explain why the 20 percent deflation of the 1930s produced the Great Depression, and why the 20 percent deflation of the 1920s produced a much milder downturn. For any of these stories to be consistent with both depressions requires that the story be quantitatively important during the 1930s, but quantitatively unimportant during the 1920s. We found that two of these four stories - unexpected deflation and debt-deflation - do not satisfy this criterion, and therefore do not seem capable of explaining the relative severity of the Great Depression. For the other two stories - imperfectly flexible wages and bank failures - we did find some differences between the 1920s and 1930s. We now develop two models - one for assessing the role of inflexible nominal wages and one for assessing the role of banking shocks

\footnotetext{
${ }^{14}$ Since deposits at failed and suspended banks are only available for commercial banks, we show this ratio relative to commercial deposits. Commercial deposits accounted for over 85\% of total deposits during 1919-23 and over $80 \%$ during 1929-34. We include failures and suspensions together since we are unaware of any data that separates these two categories.
} 
- to quantitatively evaluate how much these two factors contributed to the Great Depression.

\section{How Much of the Great Depression Was Due to High Wages?}

\section{A. A Two-Sector General Equilibrium Model}

This section presents a general equilibrium model to quantitatively assess the macroeconomic effects of high wages. Since wages in some sectors, such as agriculture, were flexible, we develop a two-sector model in which the wage in one sector is fixed above the market clearing level, and the wage in the other sector is flexible. We assume that the fixed wage in the distorted sector is equal to the manufacturing wage; this assumption is discussed in detail below. All labor hired in that sector must be paid the above-market wage. This approach captures the basic distorting effects of above-market wages but allows us to abstract from other monetary features that would complicate the environment. All other prices in the economy, including the wage in the nondistorted sector, adjust to equate supply and demand in the other markets.

We first summarize the physical environment. We then analyze the pure marketclearing version of the model with no wage distortions, and then analyze the model with above-market wages in the manufacturing sector.

\section{Environment}

Time is denoted by $t=0,1,2, \ldots, \infty$. There is a representative family with many members. Family members supply labor, consume a single physical good, and accumulate physical capital. There are two distinct types of physical goods: Final goods are the numeraire, and can be either consumed or invested to augment the capital stock. These final goods are produced using two types of intermediate goods. Each intermediate good is produced from a distinct sector. We denote the sector that will be distorted by the above-market wage as sector $m$, and the nondistorted sector as sector $n$. We denote the output of the final good by $Y$, and the output of the two intermediate goods by $Y_{i}$, where we refer to the two types of intermediate goods with subscripts $m$ and $n$. These two intermediate goods are produced using identical Cobb-Douglas technologies with capital, denoted by $K_{i}$, and labor, denoted by $H_{i}$, for $i=m, n$. The parameter $\mathrm{A}$ is labor-augmenting technological change.

Capital and labor are both sector specific - neither labor nor capital can move from 
one sector to the other. Thus, workers who are unable to work as much as they wish in the distorted sector are not permitted to move to the nondistorted sector. This assumption amplifies the distorting effects of the high wage.

\section{Technologies}

The technology for producing the $m$ intermediate good is:

$$
Y_{m}=\left(A H_{m}\right)^{1-\theta} K_{m}^{\theta}
$$

The same technology is used to produce the $n$ intermediate good:

$$
Y_{n}=\left(A H_{n}\right)^{1-\theta} K_{n}^{\theta}
$$

The technology for final goods is a CES aggregate of the two intermediate goods:

$$
Y=\left(\alpha Y_{m}^{\phi}+(1-\alpha) Y_{n}^{\phi}\right)^{1 / \phi}
$$

The parameter $A$ denotes labor augmenting technical progress.

\section{The Market-Clearing Model}

The Household's Problem. There is a representative household with many members. At date 0 , it is assumed that half of the family members work in the $m$ sector, and half work in the $n$ sector. ${ }^{15}$ The household's preferences over sequences of consumption of the final good $c_{t}$ and market time in the two sectors is given by

$$
\max \sum_{t=0}^{\infty} \beta^{t}\left[\log \left(c_{t}\right)+B\left\{\log \left(1-h_{m t}\right)+\psi \log \left(1-h_{n t}\right)\right\}\right]
$$

The household owns the capital stock and chooses consumption, $c_{t}$, work effort in the two sectors, $h_{m t}$ and $h_{n t}$, and investment, $x_{m t}$ and $x_{n t}$, to maximize (2) subject to the following present value budget constraint, capital accumulation constraint, and time constraint:

$$
\sum_{t=0}^{\infty} Q_{t}\left[w_{m t} h_{m t}+w_{n t} h_{n t}-c_{t}+r_{m t} k_{m t}+r_{n t} k_{n t}-x_{m t}-x_{n t}\right] \geq 0,
$$

\footnotetext{
${ }^{15}$ This preference specification with different utility weights on leisure permits us to retain the tractability of a representative agent formulation. The different utility weights are required when employment is different between the two sectors (e.g. $\alpha \neq 0.5$ ). It can be shown that this specification is equivalent to an environment with agents who work in either sector $m$ or sector $n$, and who are perfectly insured against idiosyncratic shocks to their specific sectors.
} 


$$
k_{i t+1}=x_{i t}+(1-\delta) k_{i t}, i \in\{m, n\} .
$$

The wage rates in the $m$ and $n$ sectors are denoted $w_{m}$ and $w_{n}$, respectively, and the rental prices of capital in the two sectors are analogously denoted $r_{m}$ and $r_{n}$. Note that the parameter $\psi$ captures the relative size difference in employment for the household. The date $t$ price of the physical good in terms of date 0 goods is denoted by $Q_{t}$.

The Intermediate Goods Firms' Problem. We assume that there is a single producer of the $m$ intermediate good, and a single producer of the $n$ intermediate good, both of whom behave competitively. ${ }^{16}$ The intermediate goods producer in sector $i, i \in\{m, n\}$, maximizes profits given $\left(p_{i}, w_{i}, r_{i}\right)$ :

$$
\max _{n_{i}, k_{i}} p_{i} k_{i}^{\theta} h_{i}^{1-\theta}-w_{i} h_{i}-r_{i} k_{i}
$$

The first-order conditions for hiring the inputs imply that factor prices are equated to the value of marginal products:

The Final Good Firms' Problem. The final goods producer also is competitive. The maximization problem is:

$$
\max _{Y_{m}, Y_{n}}\left[\left(\alpha Y_{m}^{\phi}+(1-\alpha) Y_{n}^{\phi}\right)^{1 / \phi}\right]^{1 / \phi}-p_{d} Y_{m}^{d}-p_{n} Y_{n}^{d}
$$

Equilibrium Conditions. A competitive equilibrium for this economy consists of sequences of allocations and a price system such that the allocations solve the household's problem subject to it's budget constraint, and given prices, that the allocations solve the firm's problem, given prices, that the labor market, the capital services market, the intermediate goods market all clear, that the resource constraint is satisfied, and that prices are equal to marginal productivities.

\footnotetext{
${ }^{16}$ We assume a single firm that behaves competitively, rather than a large number of competitive firms, to economize on notation.
} 


\section{The Model with Some Wages above the Market Clearing Level}

We now modify our model so that the wage in sector $m$ is set above its market clearing level. Rather than develop a monetary model with fixed nominal wages and deflation, we adopt a much simpler specification that captures the distorting effects of above-market wages. At the start of period $t$ the wage is fixed exogenously for that period at a level above its normal market-clearing level. We denote this fixed wage by $\bar{w}_{m t}$. All labor hired in this sector at date $t$ must be paid this wage. The above-market wage is a completely unexpected shock each period. ${ }^{17}$

The fixed wage changes our model in one key way: labor input in this sector is no longer a choice variable for the household. ${ }^{18}$ The households are rationed in terms of their labor supply to this sector:

$$
\frac{B}{1-h_{m t}}>\frac{\bar{w}_{m t}}{c_{t}} \text {. }
$$

Labor input in the distorted sector is determined by firms' labor demand. The representative firm hires labor until the fixed wage is equated to labor's value of marginal product:

$$
(1-\theta) p_{m t}\left(K_{m t} / H_{m t}\right)^{\theta}=\bar{w}_{m t} .
$$

The high wage has direct and indirect effects on aggregate output. We define the direct effect as the change in aggregate output from the increase in the distorted wage, holding all other prices fixed. This effect is measured by solving for $y_{m}$ from (7), given $\bar{w}_{m t}$ and holding $p_{m t}$ fixed, and then solving for aggregate output, holding $y_{n}$ fixed. The indirect, or general equilibrium, effects of the high wage operate through changes in prices and the other wage. These indirect effects depend not only on $\bar{w}_{m t}$, but also on all the model parameters. Assessing the quantitative effects of the high manufacturing wage on the economy thus requires choosing parameter values and numerically computing the equilibrium path of the model economy.

\footnotetext{
${ }^{17}$ There are many ways to model household beliefs about future distortions to manufacturing wages. Our approach, in which households believe that the fixed manufacturing wage does not recur, treats each wage shock as a completely unexpected event. As we show later, this approach simplifies computing the equilibrium considerably. This approach is also consistent with the prevailing view that the Great Depression was the result of unexpected shocks.

${ }^{18}$ Since no other markets are distorted, all other equations in the model will continue to be satisfied.
} 


\section{B. Choosing Parameter Values and Computing an Equilibrium Technology and Preference Parameter Values}

Several of the parameters in our model are commonly used in the equilibrium business cycle literature. We choose values for these parameters that are similar to values in other studies. Since the data are available at an annual frequency, we define the unit of time in the model to be one year.

The common parameters in our model are $\beta, A, B, \delta$, and $\theta$. We set $\beta=0.96$, which is comparable to values used in other studies. We assume that the level of technological

progress, $A$ is given by $A_{t}=(1+g)^{t}$, and choose $g=0.02$. Our values for $\beta$ and $g$ imply a steady-state interest rate of about 6 percent. We choose $B$ such that the household works about $1 / 3$ of their discretionary time in the steady state. The additional leisure parameter $\psi$ is chosen so that in the undistorted version of the model, the household chooses to allocate the appropriate fraction of labor to each sector at a common wage. We set $\theta=0.33$, and the depreciation rate to 7 percent.

The final parameter we discuss in this section is $\phi$, which governs the substitution elasticity between the two sectors in final goods production. Since manufacturing appears to be a key sector distorted by the high wage during the Depression, we use postwar data on changes in manufacturing's expenditure share and relative price to choose a value for $\phi$. Manufacturing's expenditure share and relative price have both fallen over the postwar period, which is consistent with a substitution elasticity between manufacturing and nonmanufacturing of less than one. We choose a benchmark value of $\phi=-1$, which implies a substitution elasticity of 0.5. We also conduct our analysis with a low substitution elasticity of 0.1 to assess the robustness of our results.

\section{The Distorted Wage and the Relative Size of the Distorted Sector}

Finally, we need to choose a measure of how much real wages rose in the distorted sector, and we need to choose a value for the fraction of the economy distorted by the high wage.

We use Hanes' (1996) compilation of the Conference Board's manufacturing wage data as the measure of the wage for the distorted sector. This wage is shown in Table 5 for each year of the Great Depression. The Conference Board wage data have also been 
used in some other analyses of the Great Depression, including O'Brien (1989), Lebergott (1990), Bernanke (1986), and Bernanke and Carey (1996). This wage is the most natural choice for a distorted wage in this study, because the data is of relatively high quality, and because there is a plausible economic explanation for why manufacturing wages were above market clearing despite the downturn in economic activity: government intervention. This intervention comes from President Herbert Hoover's belief that maintaining nominal wages would prevent a major depression by keeping demand high. In a White House meeting, Hoover asked the C.E.O.'s of major manufacturing corporations to not cut their wages. They agreed to maintain wages, and seemed to honor that agreement during the first two years of the Great Depression - manufacturing wages fell only 4.4 percent between December 1929 and September 1931. (See Lamont (1930) for a description of the meeting). ${ }^{19}$

It is worth noting that there are also manufacturing wage surveys produced by the the Bureau of Labor Statistics (BLS) that could be used to measure the distorted wage, but these surveys do not cover all manufacturing industries, and they suffer from sampling problems. In particular, large firms, which tend to pay higher wages than small firms, were oversampled.

We now turn to choosing the fraction of the economy distorted by the high wage. In our model, this fraction is governed by the paramter $\alpha$. Unfortunately, we do not know of any established measures of the fraction of the economy distorted by the high wage. The data we presented earlier suggests that on average, manufacturers paid high wages, but farmers did not. But since we do not have wage measures across the entire economy of the same quality as the Conference Board's wage data, it is difficult to estimate how much of the economy was subject to high wages. $^{20}$

To address this uncertainty over the fraction of the economy distorted by the high

\footnotetext{
${ }^{19}$ The affect of this intervention, however, weakened during the last two years of the Depression. By late 1931, Gerard Swope, C.E.O. of General Electric, circulated an industrial plan that would cartelize much of the U.S. economy. Hoover denounced this plan and refused to recommend it to Congress. Nominal manufacturing wages began to fall significantly after Hoover's condemnation of the Swope plan.

${ }^{20}$ There are wage measures in some non-manufacturing sectors, and there are also BLS payroll and employment data outside of manufacturing that can be used to construct average employee compensation. A difficulty with these BLS payroll data is that the coverage is narrow in some sectors, the data does not include hours, and in some sectors the data combines all classes of workers, including executives. This last fact suggests that constructing measures of compensation per employee from these data is subject to significant compositional bias. We discuss compositional bias, and how it may have affected different wage measures during the Depression, at the end of this section.
} 
wage, we conduct our analysis for two values of the parameter $\alpha$. We first assume that the entire manufacturing sector was subject to the distorted wage. Given Hoover's view about the importance of maintaining high wages, we also assume the federal government paid the high wage. These two sectors account for about 28 percent of employment in 1929. We therefore choose a benchmark value for $\alpha$ such that this sector accounts for 28 percent of employment in the deterministic, flexible price steady state of the model. We also conduct the analysis for $\alpha=0.50$, which implies that the distorted sector was 50 percent of the economy. This choice seems to be a plausible upper bound on the fraction of the economy distorted by the high wage. This is because at least 30 percent of workers were not paid the high wage (farming and sole proprietors), and because there does not seem to be direct measures of wages of sufficient quality that indicate that half of all workers were paid wages above trend values.

\section{Computing the Equilibrium}

Computation of the equilibrium of the model with high manufacturing wages is facilitated by our assumption that each wage shock is a completely unexpected, one-time event - the household expects at each date that the economy returns to pure market clearing the following period. This permits us to compute the equilibrium for each year of the Depression (1930-33) recursively.

Since households expect the economy to return to market clearing in the following period, the value of capital next period is a function of the single state variable in the economy, the aggregate capital stock. To compute the equilibrium at date $t$ when the manufacturing wage is higher than its competitive level, we use a log-linear approximation of the right-hand side of the Euler equation from the pure market-clearing model around its steady state. This approximation allows us to estimate the marginal value of an additional unit of capital and is used with the static first-order conditions of the model to compute the equilibrium for each year of the Depression. This involves solving $N$ nonlinear equations in $N$ unknowns for

each year. We feed our measures of the manufacturing wage for 1930-33 into the model and compute the equilibrium path of the economy for these years. Our findings are presented in the next section. 


\section{Macroeconomic Effects of High Wages: 1930-33}

Tables 7-9 show the predicted path of the U.S. economy between 1930-1933 for our model with benchmark parameter values and alternative parameter values. We find that the predicted depression for all these parameter values is much less severe than the actual U.S. Great Depression.

Table 7: Predicted Great Depression $(1929=100)$

Benchmark Model

\begin{tabular}{|l|l|l|l|l|l|}
\hline Years & $\mathrm{Y}$ & $\mathrm{C}$ & $\mathrm{I}$ & $h_{m}$ & $h_{n}$ \\
\hline 1930 & 99.2 & 99.8 & 96.9 & 97.8 & 99.3 \\
\hline 1931 & 97.3 & 99.3 & 90.4 & 93.1 & 97.8 \\
\hline 1932 & 97.2 & 98.9 & 91.1 & 93.3 & 98.0 \\
\hline 1933 & 97.8 & 98.7 & 94.6 & 95.4 & 98.8 \\
\hline
\end{tabular}

Table 7 shows the equilibrium path of output, consumption, and investment from our benchmark model with about 28 percent of the economy distorted by the high wage. Predicted real output is about 1 percent below trend in 1930 and about 2 to 3 percent below trend between 1931 and 1933. Most of the decrease in economic activity occurs in the distorted sector. The high wage reduces employment in the distorted sector about 7 percent below trend. In contrast, employment in the nondistorted sector falls only about 2 to 3 percent below trend. These predicted decreases in economic activity are much smaller than the observed decreases in output, consumption, investment, and employment that occurred between 1929-33.

There are two reasons why predicted economic activity falls so little compared to the actual decrease in economic activity. First, the distorted sector is relatively small, which means that the direct effect of the high wage on aggregate output is small. Second, the indirect, general equilibrium effects tend to reduce, rather than amplify, the direct effects.

The most important indirect effect is the increase in the relative price of the manufactured good, which rises 3 to 4 percent above its steady-state level after 1930. The relative price rises because the manufactured good is in relatively scarce supply and is not highly 
substitutable with the nonmanufactured good. This increase offsets some of the distorting effects of the high manufacturing wage. Equation (7) shows that each percentage point increase in the relative price of the manufactured good effectively reduces the fixed wage by one percentage point. Thus, the 4.4 percent increase in the relative price of manufactured goods in 1931 effectively reduces the manufacturing wage from 6.8 percent above trend to just 2.4 percent above trend.

Table 8 shows a decomposition of the change in output due to the direct and indirect effects. This decomposition shows that the negative direct effects are partially offset by the indirect effects.

\section{Table 8: Decomposition of Predicted Output: \\ Direct and Indirect Effects}

Benchmark Model

\begin{tabular}{|l|l|l|l|}
\hline Years & $\% \Delta Y$ & Direct & Indirect \\
\hline 1930 & $-0.8 \%$ & $-1.5 \%$ & $0.7 \%$ \\
\hline 1931 & $-2.7 \%$ & $-6.4 \%$ & $3.7 \%$ \\
\hline 1932 & $-2.8 \%$ & $-6.3 \%$ & $3.5 \%$ \\
\hline 1933 & $-2.2 \%$ & $-4.2 \%$ & $2.0 \%$ \\
\hline
\end{tabular}

The effects of the high wage depend on all the model parameters, but in particular depend on the share parameter $\alpha$. We therefore assess the robustness of the results by increasing the distorted share of the economy to 50 percent, which in our view is a reasonable upper bound on the distorted share of the economy.

Table 9 shows the equilibrium path of the model economy with $\alpha=0.5$. This higher value in the model produces a larger decrease in economic activity, but this decrease is still much smaller than the actual Great Depression. Real output is predicted to be 4.8 percent below trend in 1932 with $\alpha=0.5$, compared to 2.8 percent below trend in the benchmark version of the model. We thus find that raising the share of the economy that must pay the high wage to 50 percent does not materially change the findings. 
Table 9: Predicted Great Depression

Large Distorted Sector

$(1929=100)$

\begin{tabular}{|l|l|l|l|l|l|}
\hline Years & $\mathrm{Y}$ & $\mathrm{C}$ & $\mathrm{I}$ & $h_{m}$ & $h_{n}$ \\
\hline 1930 & 98.7 & 99.7 & 95.0 & 97.2 & 98.9 \\
\hline 1931 & 95.6 & 98.9 & 84.2 & 91.2 & 96.4 \\
\hline 1932 & 95.2 & 98.2 & 84.9 & 91.1 & 96.5 \\
\hline 1933 & 96.1 & 97.8 & 90.1 & 93.6 & 97.8 \\
\hline
\end{tabular}

We also conducted the analysis by reducing the elasticity of substitution between the two sectors from 0.5 to 0.1 . We do not present these results because this change did not significantly affect the results. Output falls about one percentage point more than in the benchmark model and the relative price of the good from the distorted sector rises more.

These results suggest that the high wage was not the primary cause of the Great Depression. Given our measure of the wage from the manufacturing sector, our benchmark model shows that this wage accounts for about a 3 percent decline in output at the trough of the Great Depression, compared to an actual 38 percent decline. Increasing the size of the distorted sector to 50 percent, or reducing the substitution elasticity to 0.1 did not significantly change the results.

This simple model focused on the basic distorting effects of an above-market wage through two channels - the direct reduction in sectoral labor input,and the general equilibrium effects of the high wage through prices to the other sectors of the economy. One reason why the model doesn't generate a large depression is because the general equilibrium effects offset some of the distortion of the high wage. In particular, the sectoral high wage reduces output primarily in the distorted sector, and this drives up that sector's relative price and reduces the macroeconomic impact of the distortion.

This result raises the possibility that the wage story might have a better chance if the theory could be modified to eliminate the relative price increase. This approach is not likely to be succesful, however. Eliminating the relative price increase arising from the wage distortion requires substantially reducing the demand for the output of that sector. This reduction in 
demand requires a second shock. In our model, this second shock is a decline in the parameter $\alpha$, which governs the distorted sector's share of aggregate output. Reducing $\alpha$ would reduce the demand for goods from the distorted sector and would prevent the relative price of the distorted good from rising. But this higher real wage won't generate a major depression because the reduction in $\alpha$ also reduces the quantitative importance of the distorted sector and thus reduces the macroeconomic impact of that sector. ${ }^{21}$

Finally, our model indicates another difficulty with the wage hypothesis: the timing of the depression and the timing of wage increases. With the exception of 1931, real wage increases do not occur at the same time as output declines. Real output fell 13 percent in 1930, yet the real manufacturing wage remained close to trend. Similarly, real output fell more than 17 percent between 1931 and 1932, yet the real manufacturing wage was roughly unchanged between 1931 and 1932. This lack of coincidence between the timing of output changes and wage increases suggests that some other shock reduced output in these years.

Accounting for the Depression through imperfectly flexible manufacturing wages is difficult - the real wage increase is too small and affects too little of the economy, and wage increases coincide with lower output only in 1931. The hypothesis would have a better chance if wages were significantly higher and affected more of the economy, and if there was more coincidence between the timing of wage increases and the Great Depression. But as the next section describes, these factors are unlikely.

\section{Measured Wages Are Probably Biased Upwards}

We are skeptical that actual wages were as high as the manufacturing wage measures suggest. This is because the composition of employees changed during the Depression, and this compositional shift likely induces upward bias in the wage measures. Researchers who analyze the cyclical pattern of real wages argue that cyclical changes in the composition of employment leads to wage measures that are biased upwards during recessions and biased downwards during expansions. This is because hours of low wage earners tend to be much more sensitive to the business cycle than hours of high wage earners. Consequently, the

\footnotetext{
${ }^{21}$ This discussion hightlights the problems associated with focusing on the product wage instead of the real wage. In particular, high product wages result from a combination a postive shock to real wages and a negative shock to product demand.
} 
average employed worker during a recession tends to be a higher wage earner than the average employed worker during an expansion.

Lebergott (1990) and Margo (1993) argue that compositional effects may have been particularly important during the Great Depression. Lebergott argues that compositional shifts in employee quality and in the quality of operating establishments may result in measured wages substantially overstating actual wages. He indicates that layoffs were concentrated among low-wage, young workers, which tends to increase the average measured wage of those individuals remaining employed. He also notes that relatively young firms, rather than older established firms, failed during the Depression, and that these younger firms tended to pay significantly lower wages. This compositional change also raises the average measured wage of those individuals remaining employed. Margo makes a very similar point regarding compositional bias. ${ }^{22}$

How large are these biases? Lebergott cites some microeconomic evidence which, he argues, points to significant upward bias arising from changes in employee quality. He notes that Westinghouse and General Electric retained their most productive employees during the Depression, and also cut these employees' wages by 10 percent between 1929 and 1931. However, the Conference Board's wage survey for this industry, which was heavily influenced by these two firms, shows that wages were unchanged during this period. This deviation between the wages paid by these two firms and the survey wage is likely due to changes in the composition of employees at the two firms. ${ }^{23}$ While this microeconomic example suggests the possibility of important compositional biases, we do not have the necessary individual wage and employment data to measure aggregate compositional effects. To obtain

\footnotetext{
${ }^{22}$ There is also evidence that some firms reclassified workers down (e.g., a foreman works as an assembly line worker). (See Bernanke and Carey (1996) and Lebergott (1991)). This would tend to bias wages in the opposite direction if the individual's wage was unchanged, but the value of the individual's marginal product fell. It is unclear, however, whether reclassified workers' wages were changed as a consequence of the reclassification.

${ }^{23}$ Lebergott notes that these two firms laid off low productivity workers, re-assigned some higher skilled workers, and assigned the retained workers to either 2,3, or 4 day workweeks, depending on worker ability, with the most productive workers receiving 4 day workweeks. Lebergott clearly interprets these personnel decisons and their impact on the measured wage as an example of upward compositional wage bias. As we noted above, this interpretation is clearly warranted provided that those re-classified employees who performed different tasks were paid their value marginal product. If these employees were paid in excess of their value marginal product, however, this effect would tend to offset the the upward wage bias resulting from the change in the composition of employees and the allocation of work towards the most productive employees.
} 
a rough idea of how compositional shifts may have affected measured wages more broadly, we compute estimates of compositional bias from the Current Population Survey (CPS) and the Panel Study of Income Dynamics (PSID) . We estimate the bias using two separate computations. The first computation is motivated by Lebergott's argument that employment loss was concentrated among the lowest wage earners. Determining how this compositional shift affects the wage requires specifying how employment loss was distributed during the Depression. To capture Lebergott's argument, we assume that the bottom 20 percent of wage earners lost employment and that the remaining employment loss was evenly distributed across all other workers. Using CPS data from 1998 for all full-time workers, we find that the average wage for the top 80 percent of wage earners is about 15 percent higher than for all full-time wage earners. This implies that the average wage during the Great Depression may have been overstated by 15 percent if the distribution of employment loss was concentrated among low wage earners in this fashion, and if the wage distribution in the 1930s was similar to the wage distribution today. ${ }^{24}$

Our second computation uses measures of cyclical compositional wage bias from postwar data to estimate the compositional bias in the Depression. Solon, Barsky, and Parker (1994) estimate the difference between the response to fluctuations in output relative to trend between aggregate wages and individual wages from the PSID. This difference is a direct measure of the compositional bias from using aggregate wages as a measure of an average wage, and the bias is an increasing function of the magnitude of the decrease in output. Applying their estimates to the Depression suggests that compositional shifts biased measured wages up by about 18 percent. ${ }^{25}$

While we cannot draw a firm conclusion about the quantitative magnitude of compositional wage bias during the Depression, these estimates suggest that measured wages may be substantially upward biased. ${ }^{26}$ This suggests that manufacturing wages may have been signif-

\footnotetext{
${ }^{24}$ We thank Daniel Hamermesh for performing this computation. The data is from the CPS-ORG 1998. Full-time workers are defined as those working 35 or more hours per week.

${ }^{25}$ Solon, Barsky and Parker (1994) only reported the differences in the coefficient between the fluctuations in the coefficient on the unemployment rate relative to trend. We thank Jonathon Parker for computing their estimates using real chain-weighted GDP rather than unemployment.

The measure of the compositional bias is: $(.558-.0896) *(\log (\operatorname{dGDP}(1933) / \mathrm{dGDP}(1929))$, where dGDP is the deviation of real GDP per adult from trend.

${ }^{26} \mathrm{It}$ is interesting to note that the cross-sectional differences in employment and wages between manufac-
} 
icantly below trend at the trough of the Great Depression after correcting for compositional bias. ${ }^{27}$

\section{How Much of the Great Depression Was Due to Banking Shocks?}

This section asks how much banking shocks contributed to the Great Depression. Unfortunately, there is no standard version of the neoclassical growth model with financial intermediation to use for this purpose, nor is there a standard definition of the banking shock - at least not as an explicit shock to primitives, technologies or endowments, that can be used in a general equilibrium model. We therefore develop a simple, benchmark neoclassical model in which banking output, which is produced with deposits and information capital, is an input into production of the economy's final good. We define the banking shock to be the stock of information capital lost as a consequence of bank closings. This definition is consistent with the literature which associates the banking shock with bank failures and the destruction of information capital. We use the model to address three questions: How much did bank closings reduce intermediation capital? How much did this loss of intermediation capital reduce output? Are the predicted effects of bank closings on other variables consistent with the data?

turing and farming are consistent with significant compositional bias. Since the bias should be most severe for sectors in which employment fell substantially, we should observe relatively high wages associated with low employment. Manufacturing hours fell more than 40 percent, and measured wages were about five percent above trend. In contrast, farm hours remained near trend, and measured wages fell substantially.

${ }^{27}$ Bordo, Erceg, and Evans (BEE, 2000) construct a measure of hourly employee compensation that rises about four percentage points more than the Conference Board's measure of hourly manufacturing wages, and use changes in this measure as a proxy for changes in the average wage during the Great Depression. There are two reasons why the change in their average compensation measure may deviate considerably from the change in the average person's wage during the Depression. First, as we noted before, it is difficult to infer individual wage changes from an aggregated compensation measure because of compositional shifts in employment. Thus, their compensation measure is also subject to upward bias under the assumption that layoffs were concentrated among low wage earners. Second, there is an inconsistency in their construction of total hours worked which is used in measuring average hourly compensation. In particular, their measure of total hours worked is equal to the product of full-time equivalent employees (from the NIPA) multiplied by Kendrick's (1961) average hours worked for full-time equivalent workers, which includes not only employees, but also proprietors and unpaid family workers. These latter two groups are quantitatively important, accounting for about 38 percent of Kendrick's full-time equivalent workers in 1929 (see p. 304). For BEE's caclulation, this measure of hours would be correct only if fluctuations in proprietor and unpaid family hours were identical to fluctuations in employee hours. 


\section{A. A Model with Financial Intermediation}

Our model extends the standard neoclassical growth model by requiring that some investment be intermediated. This modifies the standard model to include both internally and externally financed investment. In our model, a fraction of the capital stock is transferred from households to firms by an intermediation technology that uses real resources. This intermediation technology gives rise to borrowing and lending rates. The model allows us to analyze the effects of shocks to the intermediation technology on output, intermediated and internally financed investment, and borrowing and lending rates.

We now describe the model in detail. There are two plants that produce a single physical good using capital. At the beginning of the period there are three types of capital: installed physical capital at each plant, which we denote by $K_{1}$ and $K_{2}$, respectively; uninstalled physical capital, which is held by households and is denoted by $D$; and intermediation capital, which we denote by $Z$. Intermediation capital is in fixed supply.

The capital stocks at each plant can be increased during the period with uninstalled capital. We denote by $x_{1}$ and $x_{2}$ the amounts that are installed during the period. This uninstalled capital must be intermediated, and some of this capital is used up during the intermediation process. The capital available for production is thus $K_{j}+x_{j}$. At the end of each period, some output is used to costlessly augment the capital stock at each plant, and the remainder is distributed to households who either consume it or hold it as uninstalled capital for the following period.

The plant technologies are subject to an i.i.d. shock, which is realized at the beginning of each period. The production shock can take on two levels: $\varepsilon_{h}$ and $\varepsilon_{l}$, where $\varepsilon_{h}>\varepsilon_{l}>0$. One plant receives the high shock $\varepsilon_{h}$, and one plant receives the low shock $\varepsilon_{l}$. Each plant has an equal probability of receiving the high productivity level, and we normalize the shocks so that $0.5\left(\varepsilon_{h}+\varepsilon_{l}\right)=1$.

After the idiosyncratic plant productivity shock has been realized, uninstalled capital is allocated to the two production plants according to

$$
\sum_{j=1}^{2} x_{j} \leq G(D, Z) .
$$

We will assume that $G$ exhibits constant returns to scale (CRS) and that $G(D, Z) \leq D$. The 
resources used in the intermediation process are the quantity $D-G(D, Z)$.

Plant output is produced from a CRS Cobb-Douglas technology that uses capital and labor. For simplicity, we assume that there is one unit of labor at each plant, and that labor is in fixed supply. Plant output is given by

$$
y_{j}=A \varepsilon_{j}\left(K_{j}+x_{j}\right)^{\gamma}
$$

Plant output is used for either consumption or investment. Investment from retained output has no intermediation cost. The resource constraint for this economy is

$$
\sum_{j}\left[A \varepsilon_{j}\left(K_{j}+x_{j}\right)^{\gamma}-K_{j}^{\prime}\right] \geq c+D^{\prime}
$$

where $D^{\prime}$ denotes the next period's level of uninstalled capital and $K_{j}^{\prime}$ the amount of capital installed at plant $i$ at the beginning of the next period. We require that output net of retained investment be nonnegative.

The social planning problem for this economy is given by

$$
\text { P1: } \max _{\left\{c_{t}, x_{i, t}, K_{i, t+1}, D_{t+1}\right\}} \sum_{t=0}^{\infty} \beta^{t} u\left(c_{t}\right)
$$

subject to

$$
\begin{aligned}
& G\left(D_{t}, Z\right) \geq \sum_{j} x_{j, t} \\
& \sum_{j}\left[A \varepsilon_{t, j}\left(K_{t, j}+x_{t, j}\right)^{\gamma}-K_{t+1, j}\right] \geq c_{t}+D_{t+1} \\
& A \varepsilon_{j t}\left(K_{j t}+x_{j t}\right)^{\gamma}-K_{j t}^{\prime} \geq 0 \text { for each } \mathrm{j}=1,2 \text { and } t \\
& x_{j t} \geq 0 \text { for each } j=1,2 \text { and } t .
\end{aligned}
$$

We assume that the difference in the $\varepsilon_{h}$ and $\varepsilon_{l}$ is small enough that the nonnegativity constraint on retained earnings given in equation (11) never binds. Since the productivity shocks are i.i.d., it is optimal to set $K_{1}=K_{2}=K / 2$. Thus, we aggregate plant capital and define the state variables to be $(K, D)$.

The solution to this planning problem can be decentralized as a competitive equilibrium. This allows us to solve for equilibrium borrowing and lending rates. We assume 
competitive profit maximizing firms operate each plant. We also assume that there is a competitive profit maximizing intermediary who operates the intermediation technology. This intermediary receives funds from the household at the savings rate $1+r_{s}$ and loans it out at the borrowing rate $1+r_{b}$.

In equilibrium, the marginal cost of additional capital to the high productivity plant, $1+r_{b}$, must be equal to its marginal productivity:

$$
1+r_{b}=\gamma A \varepsilon_{h}\left(K / 2+G\left(D_{t}, Z\right)\right)^{\gamma-1}
$$

Similarly, the interest rate on savings must be just equal to the return on uninstalled capital:

$$
1+r_{s}=\gamma A \varepsilon_{h}\left(K / 2+G\left(D_{t}, Z\right)\right)^{\gamma-1} G_{D}\left(D_{t}, Z\right)
$$

The spread between these two rates is

$$
r_{b}-r_{s}=\gamma A \varepsilon_{h}\left(K / 2+G\left(D_{t}, Z\right)\right)^{\gamma-1} G_{Z}\left(D_{t}, Z\right)
$$

Note that this spread is a decreasing function of the level of intermediation capital, $Z$. Thus, a decrease in $Z$ will raise the spread between these two rates. It can also be shown that a decrease in $Z$ will reduce output and the quantity of intermediated capital, but will increase the quantity of internally financed capital as firms substitute out of intermediation into internal finance. These results are presented in the Appendix.

\section{B. How Much Did Bank Closings Reduce Intermediation Capital?}

Our model provides a measure of the banking shock - the loss of intermediation capital as a consequence of bank closings. Assuming that intermediation capital is in fixed supply and is bank specific, the fraction of intermediation capital lost due to bank closings is equal to the fraction of deposits in suspended/failed banks. This implication follows directly from the constant returns-to-scale intermediation technology. We therefore infer from the deposit data presented in Table 6 that bank closings cumulatively reduced intermediation capital about 8 percent between 1930-32 and about 19 percent between 1930-33.

\section{How Much Did the Banking Shock Reduce Output?}

We now use our model to evaluate the contribution of this decrease in intermediation capital to the Depression. Fixing $\left(K_{t}, D_{t}\right)$, the elasticity of output with respect to interme- 
diation capital is given by

$$
\frac{d Y_{t}}{d Z_{t}} \frac{Z_{t}}{Y_{t}}=\frac{\varepsilon_{h}\left(K_{t} / 2+G\left(D_{t}, Z_{t}\right)\right)^{\gamma-1} \gamma G_{Z}\left(D_{t}, Z_{t}\right) Z_{t}}{Y_{t}}
$$

The numerator of the right-hand side is the total return to intermediation. Therefore, the left-hand side of this equation is the intermediation sector's share of value added. This valueadded share elasticity result is not specific to our model. In fact, any model with a constant returns to scale technology for producing final goods has the feature that, to a first-order approximation, the elasticity of the final good with respect to any intermediate good is equal to that good's share of value added.

Banking's share of value added was about 1 percent in the 1930s. In fact, the valueadded share of the entire finance, insurance, and real estate sector (FIRE) was only about 13 percent in 1929, and dropped to 11 percent in $1933 .^{28}$ Note that this value added measure actually overstates the elasticity, since our model attributes all of banking's value added to intermediation capital. Some of this sector's value-added will be paid to labor, which means that the elasticity of output with respect to intermediation capital is actually lower than the share of value added. With this small elasticity, our model predicts that the decrease in intermediation capital caused by bank closings reduced output less than 1 percent between 1929-33.

\section{Can a Low Substitution Elasticity Plausibly Magnify the Shock?}

The macroeconomic effect of destroyed intermediation capital would be larger if bank finance and alternative forms of finance or other inputs were poor substitutes. A low substitution elasticity, however, is inconsistent with the data. If banking shocks were an important contributing factor to the Depression and this substitution elasticity was very low, the cost share of banking and of FIRE should have increased considerably during the 1930s. In contrast, the cost share of FIRE falls from 13 percent in 1929 to 11 percent in 1933, and banking's cost share falls from about 1.4 percent to about 1 percent over the same period. ${ }^{29}$

\footnotetext{
${ }^{28}$ Banking accounted for 10 percent of value added in FIRE in 1947. Kuznets (1941) reports a similar number for the period between 1919-1938.

${ }^{29}$ The data on banking's cost share is from Kuznets (1941), page 731
} 


\section{Can Externalities Magnify the Impact of the Shock? Evidence from State-Level Data}

An externality associated with intermediation capital could increase the economic impact of this intermediation shock. One drawback to the externality story is that there are many different ways of putting externalities into models, but often these externalities do not have strong micro foundations, nor are they straightforward to quantitatively evaluate. The banking/Depression literature, however, suggests a specific type of externality that is straightforward to assess. This literature argues that bank failures reduced output by destroying local bank information, and thus suggests a productive externality associated with intermediation capital that affects local production. We therefore consider a version of our model in which there are $N$ regions, and aggregate output is the sum of regional outputs.

Suppose that output in region $i$ is given by:

$$
Y_{i}=Z_{i}^{\delta} \sum_{j=1}^{2} A \varepsilon_{t, i j}\left(K_{t, i j}+x_{t, i j}\right)^{\gamma} H_{i j}^{1-\gamma}
$$

where $Z_{i}^{\delta}$ is the productive externality from intermediation capital in region $i$. This version of our model predicts that regions that experience many bank closings should also experience relatively large depressions. We assess this prediction by first defining a region as a state and then computing the correlation between bank suspensions/failures and economic activity across the 48 U.S. states during the Great Depression. Note that this comparison is a regional extension of Bernanke's (1983) influential paper which found that aggregate bank suspensions/failures were negatively correlated with aggregate output.

Figure 1 shows a scatter plot of the sum of suspended/failed deposits from 192933 relative to total deposits in 1929 vs. the percentage change in nominal personal income between 1929 and 1933 by state. The most striking feature of these data is that the significant negative correlation between bank closings and output documented by Bernanke (1983) at the aggregate level does not emerge at the state level. ${ }^{30}$ The plot shows no systematic relationship between the concentration of banking shocks and the severity of the Depression across states. The correlation between suspended deposits and nominal income is -0.15 and is not significantly different from zero. A regression of the percentage change in personal income

\footnotetext{
${ }^{30}$ Temin (1989) also notes that some bank failure episodes were very regionally concentrated.
} 
divided by the aggregated GDP deflator on the fraction of deposits in suspended/failed banks yields an $R^{2}$ of 0.014 and a slope coefficient that is not significantly different from zero. ${ }^{31}$ We also examined the relationship between the same measure of deposits and an alternative statewide measure of real economic activity - the percentage change in manufacturing employment between 1929-33. ${ }^{32}$ Figure 2 shows a scatter plot between these two variables. The correlation between these data is, in fact, positive, rather than negative: $0.12 .^{33}$

These data do not support the standard banking story for the Great Depression: that bank closings reduced output by destroying local information capital. The relatively small bank shock, combined with banking's small share in the production function, and the lack of any correlation between state-level bank closings and economic activity indicate that if banking was an important contributing factor during the Great Depression, it must have operated through some alternative mechanism in which the shock was much larger and was operative at the aggregate level rather than the regional level. We analyze an alternative mechanism in the following section.

\section{Other Shocks to Bank Capacity}

An alternative banking story is that depositors were afraid of bank runs and consequently withdrew deposits from all banks. This alternative story would have a better chance than the bank failure story if the decrease in deposits resulting from depositor fear was substantially larger than the decrease in deposits at closed banks. This story is difficult to evaluate, however, because it is unclear how much of the decrease in total deposits was due to depositor fear and how much was an endogenous response to the large decrease in overall economic activity. Consequently, we can't measure the size of this shock associated with depositor fear.

Despite this measurement problem, our model makes one specific prediction about

\footnotetext{
${ }^{31}$ We estimated two other versions of this equation. To control for level affects, we defined a dummy variable that takes the value of 1 if a state's per-capita income was above the median. We used this dummy variable to analyze an intercept shift, and an intercept shift and slope coefficient shift. The results were quite similar to the simpler specification.

${ }^{32}$ These data are from the bi-annual Census of Manufacturers.

${ }^{33}$ The lack of a systematic pattern between bank closings and economic activity at the state level raises the possibility that the correlation between aggregate bank closing and aggrgate output may indicate that aggregate bank closings are proxying for another variable. This is consistent with Green and Whiteman (1992).
} 
this story that can be evaluated. According to this story, banking services are in relatively scarce supply because of deposit withdrawal. The model predicts that an exogenous decrease in deposits will decrease the deposit/output ratio. This result is not specific to our model, but follows directly from constant returns to scale in production and the relative scarcity of deposits. The actual deposit/output ratio, however, differs considerably from with this prediction. Table 6 shows that the deposit/output ratio rises from 0.58 to 0.78 between 1929-32. This increase in the deposit/output ratio implies that deposits were not relatively scarce during the Great Depression.

Even if deposits were relatively scarce because of depositor fear, however, there is no theoretical presumption that this would generate a massive depression because banking's share of value added is small. In fact, these cost share statistics suggest a presumption that banking shocks should tend to have small, rather than large macroeconomic effects. The Irish bank strikes of the 1960s-70s provides evidence that is consistent with this latter view. Murphy (1978) reports that on three occasions between 1966 and 1976, industrial disputes led to the shutdown of the Associated Banks, which accounted for over 80 percent of Irish M2. These strikes, the longest of which was six-months, represent negative, exogenous shocks to the banking sector that are larger than any plausible bank capacity shock that might have occurred during the U.S. Great Depression .The macroeconomic effects of these strikes, however, were small. During the longest strike, detrended retail sales fell about four percent, and real output rose over the full calendar year of 1970. Murphy argues that the strike did not have important effects because households and firms developed substitutes for bank services, including private trade credit. These "natural experiments" show that a long-term shutdown of most of a country's banking system - a shutdown much larger than that which occurred during the Great Depression - need not substantially reduce economic activity.

These data are inconsistent with the view that the Depression was caused by a large exogenous decrease in deposits. Instead, they are consistent with the view that the decrease in deposits may have been primarily an endogenous response to the overall decline in economic activity. 


\section{E. Other Implications of a Banking Shock}

Our analyses of the banking story - through an explicit shock based on bank closings and through an alternative story based on a decrease in overall bank capacity - do not support the view that banking was an important contributing factor to the Great Depression.

Of course, any explicit analysis along these lines depends on a definition and measure of the banking shock. Some other aspects of the banking story can be assessed without an explicit definition and measure of this shock. Our model makes two such predictions. The first prediction is that any reduction in banking capacity should increase the spread between deposit and loan interest rates. The second is that any reduction in the availability of intermediated loans, or any increase in the cost of intermediated loans, should lead firms to substitute out of external finance and into internal finance.

\section{Impact of the Banking Shock on the Cost of Intermediation}

Our model predicts that a negative shock to the banking sector increases the spread between the interest rate on intermediated debt and the bank's cost of funds. Before examining changes in interest spreads, it is important to recognize that these spreads are affected not just by intermediation shocks, but also by changes in loan maturity, changes in the composition of borrowers, and changes in default risk. Since these other factors may have changed significantly during the Great Depression, it is very difficult to separately identify changes in interest spreads that are due to changes in the intermediationtechnology.

This identification problem leads us to make two comparisons of interest rate spreads. We first examine an interest rate spread between a collateralized, short-term obligation and short-term Treasuries during the Great Depression. This comparison permits us to reasonably control for some of the other factors affecting interest spreads: both securities have roughly constant maturities, and the collateralized nature of the private obligation limits the effect of changes in either default probability or the composition of borrowers.

Our second comparison presents the spread between long-term, quality-rated corporate securities and government bonds during the Great Depression. This analysis has been conducted in the previous literature for low quality corporate debt. However, the change in this low-quality spread cannot be solely attributed to intermediation shocks because default 
risk on these lower quality securities increased during the Great Depression. Consequently, it is unclear how much of the change in the spread was due to intermediation, and how much was due to higher default risk. To confront this identification problem, we present spreads on high quality securities whose default risk may not have changed much during the Depression. If a negative intermediation shock was important, spreads on all types of securities would be expected to rise in the 1930s. Alternatively, if the spread on low quality debt was higher largely because of changes in default risk, the spread should be roughly unchanged for the highest quality securities, but should rise for lower quality securities.

Table 10: Banker's Acceptance Rates and Government Security Yields ${ }^{34}$

\begin{tabular}{|l|l|l|l|l|l|l|}
\hline Year & 1928 & 1929 & 1930 & 1931 & 1932 & 1933 \\
\hline (1) Bankers Acceptances & 4.09 & 5.03 & 2.48 & 1.57 & 1.28 & 0.63 \\
\hline (2) Short-Term Gov. Debt & 3.97 & 4.42 & 2.23 & 1.15 & 0.78 & 0.26 \\
\hline$(1)-(2)$ & 0.12 & 0.61 & 0.25 & 0.42 & 0.50 & 0.37 \\
\hline
\end{tabular}

We first analyze our measure of the short-term spread. Table 10 presents the spread between 3 to 6 month Banker's acceptances and 3 to 6 month Treasury notes. The Banker's acceptances are collateralized, which controls for changes in default risk. Since the bank that originally discounted the bill stood as the guarantor of its ultimate payment, it is important to note that the bank performed an important intermediation function in the production of this asset. Consequently, a negative shock to the intermediation technology should have increased the spread between these two securities. The table shows that the spread between the rate on banker's acceptances and Treasuries does not change much during the Depression. The stability of this interest rate spread therefore indicates that the efficiency of this type of intermediation was not impaired during the Depression. ${ }^{35}$

We next examine the spread between the rates on corporate bonds, which are a substitute for bank finance for large firms, and U.S. government bonds. Table 11 shows the spread

\footnotetext{
${ }^{34}$ The data are from the Board of Governors of the Federal Reserve System (1943).

${ }^{35}$ The gap between commercial loan rates and short term government securities rose about 250 basis points during the Depression. The gap between commercial loans and government bonds, however, narrowed by about 120 basis points. Given the caveats mentioned above, plus a steepening in the yield curve, it is not clear how to interpret these changes.
} 
for corporate bonds of different qualities - Aaa (lowest default risk), Aa, A, and Baa. There are two striking features of these data. First, the average increase in interest spreads is fairly small. Second, the magnitude of the increases in the spread is directly related to the quality of the debt: the average spread changes very little for high quality debt, but increases for lower quality debt.

Table 11: Interest Rate Spreads Between Corporate and Government Bonds ${ }^{36}$

\begin{tabular}{|l||l|l|l|l|l|l|}
\hline Years & 1929 & 1930 & 1931 & 1932 & 1933 & Avg. \\
\hline Aaa - Gov & 1.13 & 1.26 & 1.24 & 1.33 & 1.18 & $\mathbf{1 . 2 5}$ \\
\hline Aa - Gov & 1.33 & 1.48 & 1.71 & 2.30 & 1.92 & $\mathbf{1 . 8 5}$ \\
\hline A - Gov & 1.68 & 1.84 & 2.67 & 3.52 & 2.78 & $\mathbf{2 . 7 0}$ \\
\hline Baa - Gov & 2.30 & 2.61 & 4.28 & 5.62 & 4.45 & $\mathbf{4 . 2 4}$ \\
\hline
\end{tabular}

These data are consistent with the view that changes in default risk were an important contributing factor to higher spreads. To illustrate how these changes could have affected spreads, suppose that Baa securities pay off 60 percent of the principal if the firm defaults. With this assumption, the 230 basis point spread between Treasuries and Baa bonds in 1929 implies that the default probability for Baa bonds was about 5 percent at that time. It also implies that the average 424 basis point Baa spread during the Depression can be completely explained by an increase in this default probability from 5 percent to 8 percent. This increase does not seem implausible during this period. ${ }^{37}$

While we cannot draw a firm conclusion about the quantitative importance of changes in default risk, it is certainly true that default risk rose during the Depression and thus contributed to higher spreads. But even if we abstract from default risk and completely attribute these higher spreads to negative intermediation shocks, it seems unlikely that these increases - ranging from 12 basis points to 194 basis points - can plausibly explain the Great Depression. If higher spreads were the key to understanding the Great Depression, they

\footnotetext{
${ }^{36}$ The data are from Banking and Monetary Statistics, BoG.

${ }^{37}$ Cole and Ohanian (2000) present a monthly analysis of these spreads, which permits a closer examination of changes in spreads with the onset of banking crises. We did not find much evidence of large increases in interest spreads around these periods. .
} 
should have increased much more during the Depression than during milder recessions. But this is not the case. The average rise in the Baa-Treasury spread for all post-World War II recessions is more than 200 basis points. This includes several recessions in the 1970s and early 1980s in which this spread rose as much as 500 basis points. All of these recessions were much milder than the Great Depression, despite these much larger interest spread increases.

In summary, interest spreads did not rise much outside of low-quality corporate securities, and it is unclear how much of this increase is due to intermediation shocks. Moreover, the average increase in spreads does not seem to be nearly large enough to account for the magnitude of the Great Depression. In the following section, we present the second prediction of our model that does not rely on an explicit definition of the banking shock. Our model shows that if a negative banking shock increased the cost of funds and disrupted economic activity, firms should have increased retained earnings.

\section{Impact of Banking Shocks on Other Sources of Finance.}

The theory predicts that a reduction in the availability of intermediated finance, or an increase in the cost of intermediated finance, should lead firms to substitute out of intermediated finance and increase retained earnings. Figures 3 and 4 show real profits, dividends, and retained earnings per adult relative to trend in the entire corporate sector and in the manufacturing subsector, respectively. The most striking feature of these data is that firms were not increasing retained earnings as the theory predicts. In sharp contrast, retained earnings fell substantially as firms maintained relatively high dividend payments. Corporate profits fell by nearly 40 percent between 1929 and 1930, but dividend payments fell by only about 4 percent. Profits decreased by over 70 percent between 1929 and 1931, but dividend payments fell by only 25 percent during this period. By 1932, corporations experienced substantial losses, but retained earnings fell even more as firms maintained dividend payments equal to 51 percent of their 1929 level. This pattern also emerges at the sectoral level. Figure 4 shows that a very similar pattern prevailed among manufacturing corporations, and table 12 shows that this pattern continues among durable and nondurable manufacturers and among mining corporations. ${ }^{38}$

\footnotetext{
${ }^{38}$ There was some variance in dividend payouts at the industry level. For example, dividends in the tobacco industry were particularly high during the Depression. These outliers did not affect the sectoral
} 
The maintenance of dividend payments at the expense of retained earnings throughout the Depression suggests that firms were liquidating their enterprises, rather than finding substitutes to costly bank finance. Reconciling this large drop in retained earnings with the banking story seems difficult. To do so requires explaining why firms drained their coffers and increased their exposure to negative banking shocks.

Table 12 Profits and Dividends in Key Sectors ${ }^{39}$

(Real Per Adult and Relative to Trend)

\begin{tabular}{|l|l|l|l|}
\hline & 1929 & 1931 & 1933 \\
\hline Mining & & & \\
\hline Profits & 430 & -75 & -115 \\
\hline Dividends & 309 & 118 & 66 \\
\hline Durable Manufacturing & & & \\
\hline Profits & 2247 & -155 & -721 \\
\hline Dividends & 1335 & 811 & 314 \\
\hline Nondurable Manufacturing & & & \\
\hline Profits & 2332 & 1303 & -85 \\
\hline Dividends & 1213 & 1133 & 803 \\
\hline
\end{tabular}

\section{Interactions between the Wage and Banking Shocks}

Even though we find that neither banking shocks nor wage shocks account for much of the Great Depression, is it possible that the interaction between these two shocks has a large macroeconomic effect? There are two reasons why we do not think this is very likely. If there was an important connection between the two types of shocks, we should observe a strong negative correlation between the incidence of banking crises and economic activity in sectors distorted by high wages. Manufacturing was ostensibly distorted by the high wage, but the

level statistics much. Real nondurable manufacturing dividends in 1933 were 66 percent of their 1929 level. Excluding tobacco, these dividends in 1933 were 62 percent of their 1929 level.

${ }^{39}$ The data are from the NIPA and are measured without inventory valuation adjustment. We thank Mark Gertler for pointing out to us that this measure of profits is a better measure of cash flow (net of depreciation). They are detrended at the average rate of growth of output per adult: $1.9 \%$. 
correlation between manufacturing employment and bank closings was positive at the state level, rather than negative. Moreover, the correlation between state per-capita income and bank failures in states with large manufacturing sectors - those with above-median ratios of manufacturing employment to population - is roughly the same as that for all the states, and is not significantly different from zero.

There are also theoretical reasons for doubting that an interaction between the two shocks would have large effects. To illustrate this point, consider the simplest possible method of incorporating the banking shock into the wage model. Suppose that intermediation capital was another input into production, and denote the sectoral level of intermediation capital by $Z_{i}$. Sectoral output is now given by the production function $Y_{i}=\left(A H_{i}\right)^{1-\theta-\gamma} K_{i}^{\theta} Z_{i}^{\gamma}$, where $\theta$ is unchanged and $\gamma=0.01$ to match banking's value-added share. Given this specification, it is straightforward to show that the 18 percent decrease in $Z$ that occurred between 1929-33 would reduce output in the wage model an additional 0.18 percent. This result partially reflects the fact that the decrease in intermediation capital leads to general equilibrium changes in factor prices that moderate the impact of the factor change.

\section{What Else was Different about the Great Depression?}

The two candidate shocks we have considered - bank failures and imperfectly flexible wages - don't seem capable of plausibly explaining the Great Depression. So if it wasn't banking or wages, what other factors might have been responsible? ${ }^{40}$

\section{A. Lower Asset Prices}

The first alternative shock we examine is lower asset prices. The stock market crash of 1929 is considered by some economists to have contributed to the Great Depression (see Romer (1993)). It is difficult to evaluate this story since there currently is no generally accepted theory of asset price fluctuations. Without such a theory, one cannot establish that asset price changes contributed significantly to the Great Depression. ${ }^{41}$ But we can take a

\footnotetext{
${ }^{40}$ One difference between these two episodes is that the deflation of 1921-22 immediately followed a significant inflation, while the deflation of 1929-33 followed a period of roughly stable prices. If nominal prices were more flexible during the earlier depression, the deflation may have had smaller real effects. Little is known, however, about the differences in price flexibility during these two downturns.

${ }^{41}$ Without a good theory of asset price fluctuations, it is unclear what shock drove down asset prices, or how asset prices interacted..
} 
first step by empirically assessing whether other periods of large and prolonged decreases in asset prices also coincide with major Depressions. One of the best known of these episodes is Japan in the 1990s. We therefore compare changes in stock prices and output in the U.S. in the 1930s to Japan in the 1990s. Tables 13-14 show real stock prices and output for these two countries. We find some important similarities in asset price changes between the two countries, but very different output changes after share prices fall.

Table 13: Real U.S. Detrended Stock Prices and Output ${ }^{42}$ $(1929=100)$

\begin{tabular}{|l|l|l|l|l|l|l|l|}
\hline Year & 1926 & 1927 & 1928 & 1929 & 1930 & 1931 & 1932 \\
\hline S\&P Index & 50.4 & 61.7 & 78.2 & 100.0 & 81.4 & 57.1 & 31.6 \\
\hline Output Index & 102.8 & 100.1 & 97.7 & 100.0 & 86.9 & 77.6 & 64.0 \\
\hline
\end{tabular}

\section{Table 14: Real Japanese Detrended Stock Prices and Output ${ }^{43}$ $(1989=100)$}

\begin{tabular}{|l|l|l|l|l|l|}
\hline Year & 1986 & 1989 & 1990 & 1991 & 1992 \\
\hline Nikkei Index & 55.1 & 100.0 & 81.6 & 63.1 & 44.6 \\
\hline Output Index & 96.2 & 100.0 & 101.4 & 101.5 & 98.9 \\
\hline
\end{tabular}

Stock prices in both countries roughly doubled during the three-year period before their respective market peaks. Output growth relative to respective trends is also very similar in the two countries during these three-year periods of rising stock prices. Following their respective market peaks, stock prices fall sharply in both countries. U.S. share prices fall about 68 percent, and Japanese share prices fall about 55 percent. Despite these similar stock price patterns, output growth differs substantially after prices begin to fall. U.S. output is 36

\footnotetext{
${ }^{42}$ Source of S\&P data: Historical Statistics table X 492-498

${ }^{43}$ Quantities are not per adult, and have been detrended using a 3.7\% rate of growth which is the average rate of growth of real output between 1979-89. Output and Stock Price data are from the DRI International Database.
} 
percent below trend three years after its stock market peak, while Japanese output remains on trend three years after its stock market peak. ${ }^{44}$

These data show that large asset price decreases are not always associated with big depressions. Japanese stock prices fell nearly as much in the 1990s as U.S. share prices fell in the 1930s, but Japanese output remained close to trend while stock prices fell. ${ }^{45}$ These Japanese data and the pattern of retained earnings during the U.S. Great Depression raise questions about the asset price story. First, if lower asset prices contributed to the U.S. Great Depression, why didn't a similar decrease produce a Great Depression in Japan? Second, if the macroeconomic impact of lower prices is through lower borrower net worth, as is often presumed in the literature, then why did firms continue to pay such dividends during the 1930s rather than increase retained earnings? Finally, if decreases in asset values have a substantial negative effect on output, through either borrower or consumer net worth, then why did the increase in asset prices have so little effect in either Japan or the U.S.? Any theory of the Depression based on lower asset values should be able to explain why lower asset prices don't always produce major depressions, and explain why retained earnings fell in the $1930 \mathrm{s.}^{46}$

\section{B. The Fall in Total Factor Productivity}

The second alternative shock we consider is a total factor productivity (TFP) shock. This shock is much different during the Great Depression than other periods and in particular differs sharply from 1921-22. TFP rose about 5 percent relative to trend in 1921, but fell

\footnotetext{
${ }^{44}$ Japan did experience a growth slowndown after 1991, and by 1998 was $15 \%$ below trend. However, note that this decrease comes 9 years after the decrease in asset prices.

${ }^{45}$ Land values in Japan also followed the same rollercoaster pattern as stock prices in the 1990s. Commercial real estate values doubled during the same period that stock prices doubled, and fell 35 percent three years after the market peak. These data are thus inconsistent with the view that Japan maintained high macroeconomic activity because other asset values remained high.

(See commercial real estate prices in the 6 largest cities from the Japan Real Estate Institute: http://www.reinet.or.jp/index-e.htm.)

${ }^{46}$ These data cast doubt on the ability of theoretical models in which finanical market imperfections amplify the effects of macroeconomic shocks by reducing net worth being able to explain a significant portion of the Great Depression. (See Kiyotaki and Moore (1997), and Bernanke, Gertler, and Gilchrist (2000) (BGG)). According to these models, output should have expanded significantly when stock prices were rising. Moreover, these models predict that enterprises should have substantially increased internal cash when share prices began falling. Both of these predictions stand in contrast to the data.
} 
about 14 percent below trend between 1929 and $1933 .^{47}$

It is unlikely that this TFP decrease during the Great Depression reflects technological regress or is solely due to factor measurement error. To see this latter point, consider three types of measurement error: capital utilization, changes in labor quality, and changes in capital quality. The utilization of the capital stock was low during the Great Depression, and this overstatement of the capital input will bias down TFP measurement. But the other two sources of factor mismeasurement will tend to offset mismeasured capital input. The average quality of labor input probably rose during the Depression, as the least productive workers were probably the first to be laid off. This indicates that measures of labor input based on employment or hours worked will understate labor input in efficiency units. Similarly, the oldest, least efficient capital was idled during the Depression (Bresnahan and Raff (1991)). This "vintage effect" implies that measures of capital input based on the number of idle factories will understate capital input in efficiency units. Both of these compositional effects will tend to understate the true decline in TFP and tend to offset the impact of capital utilization.

Since labor's share is about twice as large as capital's share, considerable mismeasurement of capital utilization is required to bias the TFP measure. For example, if true capital input was 20 percent lower than measured capital input (after correcting for vintage effects), and true labor input in efficiency units was 5 percent higher than measured labor input due to compositional shifts, TFP would have decreased by 11 percent, compared to the measured decrease of 14 percent.

Negative productivity shocks also show up in disaggregated data. Bernanke and Parkinson (1991) report negative productivity shocks in manufacturing and argue that the shocks reflect labor hoarding or increasing returns to scale. But there are good reasons to question these two explanations. Recent research indicates constant returns to scale in manufacturing, rather than increasing returns. And at least the traditional reason given for labor hoarding - the costs of laying off and subsequently rehiring a worker exceeds the cost of retaining the worker- seems unlikely during this period. Managers seem to have been liqui-

\footnotetext{
${ }^{47}$ Romer (1988) argues that there was a favorable supply shock during the 1921-22 depression, although she does not discuss TFP changes.
} 
dating their enterprises during the Great Depression, rather than planning for an upcoming expansion that would have productively utilized the hoarded labor.

The TFP decrease may not be adequately explained by technological regress, factor mismeasurement, or returns to scale. More research is needed to determine the sources of and reasons for, this large change and how much it may have contributed to the Great Depression. Since a decrease in productivity reduces marginal productivity, this shock may represent the best chance for the wage hypothesis to account for a reasonable fraction of the output decrease.

\section{Summary and Conclusion}

Our results suggest that two popular stories for the Great Depression - the inflexible wage/deflation story and the banking shock story - account for a relatively small fraction of the output fall that occurred between 1929-33. The problem with the inflexible wage story does is that measured wages were above trend in only a subset of the economy, and that a reasonable correction for shifts in the composition of employment would reduce those wage measures below trend. The problem with the banking shock story is that the shock is small, and the elasticity of aggregate output with respect to a banking shock is also small. Moreover three important auxiliary predictions of the banking story don't line up with the data. The theory predicts that states that had worse banking crises should have had more worse depressions. But there is no systematic relationship between state economic activity and the number of bank closings. The theory also predicts that firms should have increased internal cash in response to the banking shock. In contrast, firms reduced retained earnings substantially during the Great Depression. The theory also predicts that the ratio of bank deposits to output should have decreased during the Depression. This ratio increases substantially during the Depression. Any successful financial intermediation theory of the Depression should be consistent with these three facts.

We conclude that the Great Depression remains a puzzle. The paper suggests two directions for future research. One direction is to analyze money/deflation shocks through alternative channels. The second direction is to analyze real shocks. The fact that real output per adult fell 13 percent in 1930 without any significant deflation suggests the possibility that 
a real shock contributed to the initial downturn. And the large decrease in TFP suggests the possibility that some shock may have affected productivity during the Great Depression. 


\section{Appendix: Characterizing the Equilibrium of the Wage Model}

In what follows, we will assume that the difference in the idiosyncratic productivity shocks is small enough that the nonnegativity constraint on retained earnings never binds. Under this assumption, the f.o.c.s that characterize a solution include

$$
\begin{aligned}
\beta^{t} u^{\prime}\left(c_{t}\right) & =\lambda_{t} \\
\lambda_{t} \gamma A \varepsilon_{t, i}\left(K_{t, i}+x_{t, i}\right)^{\gamma-1} & =\mu_{t}-\xi_{t, i} \text { where } x_{t, i} \xi_{t, i}=0 \\
\lambda_{t+1} \gamma A E_{t}\left\{\varepsilon_{t+1, i}\left(K_{t+1, i}+x_{t+1, i}\right)^{\gamma-1}\right\} & =\lambda_{t} \\
\mu_{t+1} G_{1}\left(D_{t+1}, Z\right) & =\lambda_{t}
\end{aligned}
$$

where $\mu_{t}, \lambda_{t}$, and $\xi_{t, i}$ are the Lagrangian multipliers on the constraints (9) and (10) and the nonnegativity constraints on $x_{i}$, respectively.

It is easy to see from the f.o.c. on plant capital, (15), that $K_{1}=K_{2}$. Hence we can aggregate plant capital and treat them as the state variables $(K, D)$, where $K / 2$ is plant capital. It is easy to see that $x_{l}$ cannot be positive, since condition (14) would imply that $x_{h}$ was also positive, and hence at both plants the marginal product of capital would be greater than $\lambda_{t-1}$, which would contradict (15).

The steady state of this model will be given by $(K, D)$, where

$$
\begin{aligned}
& \beta \gamma A\left[\varepsilon_{h}(K / 2+G(D, Z))^{\gamma-1}+\varepsilon_{l}(K / 2)^{\gamma-1}\right]=1 \\
& \beta \gamma A \varepsilon_{h}(K / 2+G(D, Z))^{\gamma-1} G_{1}(D, Z) \leq 1 \text {, with strict equality if } D>0,
\end{aligned}
$$

and $c$ is given by

$$
c=\frac{1}{2} A \varepsilon_{h}(K / 2+G(D, Z))^{\gamma}+\frac{1}{2} A \varepsilon_{l}(K / 2)^{\gamma}-(K+D) .
$$

We can develop the analysis further by assuming an explicit functional form for $G$. The Leontieff specification allows us to obtain closed-form solutions for the variables $D$ and $K$ :

$$
G(D, Z)=\min (\alpha D, Z)
$$

where $\alpha<1$ and $(1-\alpha) D$ is the cost of intermediation. 
If $D$ is positive and interior, that is, less than $Z$, it is straightforward to show that

$$
D=\frac{1}{\alpha}(\beta A \gamma)^{\frac{1}{1-\gamma}}\left[\varepsilon_{h}^{\frac{1}{1-\gamma}}-\left(\frac{\alpha \varepsilon_{l}}{2 \alpha-1}\right)^{\frac{1}{1-\gamma}}\right] .
$$

If the value of $D$ is such that $D \in[0, Z / \alpha]$, then the steady-state level of $K$ is

$$
K=\left(\frac{\alpha \beta A \gamma \varepsilon_{l}}{2 \alpha-1}\right)^{\frac{1}{1-\gamma}} .
$$

If the value of $D$ implied by (19) is negative, then it is easy to show that in the steady state $D=0$, and

$$
K=\left[\frac{\beta \gamma A}{2}\left(\varepsilon_{h}+\varepsilon_{l}\right)\right]^{\frac{1}{1-\gamma}} .
$$

If the value of $D$ implied by (19) is greater than $Z / \alpha$, then in the steady state $D=Z$ and $K$ is the solution to (17) when we set $G(D, Z)=Z$.

This allows us to conduct some comparative statics on what happens to $K$ and $D$ when intermediation capital changes. If $Z$ binds, then $d K / d Z<0$ and $d(K+\alpha D) / d Z>0$. Furthermore, if $D>0$, then $d(\alpha D) / d \alpha>0$, and hence $d K / d \alpha<0$, while $d(K+\alpha D) / d \alpha>0$. Our model predicts that a decrease in intermediation capital increases internally installed capital, but significantly reduces intermediated investment. Similarly, an increase in the cost of intermediation $(\alpha)$ increases internally installed capital and reduces intermediated investment. It is also easy to see how the spread in the lending and borrowing rate is affected by a change in $Z$. In this example, the marginal cost of funds to the high productivity plant must be

$$
1+r_{b}=\gamma A \varepsilon_{h}(K / 2+\alpha D)^{\gamma-1} .
$$

The interest rate on savings must be

$$
1+r_{s}=\gamma A \varepsilon_{h}(K / 2+\alpha D)^{\gamma-1} \alpha .
$$

This implies that the spread between these two rates is given by

$$
r_{b}-r_{s}=\gamma A \varepsilon_{h}(K / 2+\alpha D)^{\gamma-1}(1-\alpha) .
$$

A decrease in intermediation capital that binds will lower the quantity of intermediated capital, $\alpha D$, and raise the quantity financed out of retained earnings, $K$. It also raises both 
the borrowing and lending interest rates and the spread between them, since the marginal productivity of capital at the high productivity plant is raised. The spread also is decreasing in $\alpha$, which governs the fraction of capital consumed by the intermediation process.

Finally, assume that $G_{D}, G_{Z}, G_{D Z}>0$ for all $D, Z>0$. In this case, a reduction in $Z$ works like an increase in intermediation costs. Since $G$ is $\mathrm{CRS}, G(D, Z)=g(Z / D) D$, where $g^{\prime}>0$. In response to a decrease in $Z$, the equilibrium level of $Z / D$ would increase. This indicates that the relevant factor for intermediation costs is not the level of intermediation capital per se, but the level relative to the quantity of intermediated capital. 


\section{References}

[1] Beney, Ada, Wages, Hours, and Employment in the United States 1914-36, New York: National Industrial Conference Board, Inc. 1936

[2] Bernanke, Ben S. 1983. Nonmonetary effects of the financial crisis in propagation of the Great Depression. American Economic Review 73 (June): 257-76.Bernanke, Ben S. 1983. Nonmonetary effects of the financial crisis in propagation of the Great Depression. American Economic Review 73 (June): 257-76.

[3] Bernanke, Ben S. 1986. Employment, Hours, and Earnings in the Depression: An Analysis of Eight Manufacturing Industries. American Economic Review 76 (March) 82-107.

[4] _ _ proach. Journal of Money, Credit, and Banking 27 (February): 1-28.

[5] Bernanke, Ben S., and Carey, Kevin. 1996. Nominal wage stickiness and aggregate supply in the Great Depression. Quarterly Journal of Economics 111 (August): 853-83.

[6] Bernanke, Ben S., and Parkinson, Martin L. 1991. Procyclical Labor productivity and competing theories of the business cycle: Some evidence from interwar U.S. manufacturing industries. Journal of Political Economy 99 (June): 439-59.

[7] Bernanke, Ben S., Gertler, Mark, and Gilchrist, Simon, (2000) "The Financial Accelerator in a Quantitative Business Cycle Framework", forthcoming in The Handbook of Macroeconomics, John Taylor and Michael Woodford, eds.

[8] Board of Governors of the Federal Reserve System (1943), Banking and Monetary Statistics.

[9] Bordo, Michael, Erceg, Christopher, and Evans, Charles, (2000) "Money, Sticky Wages, and the Great Depression", forthcoming, American Economic Review.

[10] Bresnahan, Timothy and Raff, Daniel (1991) "Intra-industry Heterogeneity and the Great Depression: The American Motor Vehicles Industry, 1929-35, Journal of Economic History, June, 317-31. 
[11] Bureau of the Census, 1975, Historical Statistics of the United States, Washington D.C.

[12] Bureau of the Census, various years, Biennial Census of Manufacturing, Washington D.C.

[13] Cechetti, Steve (1992) "Prices and the Great Depression": Was the Deflation of 1930-32 Really Unanticipated?", American Economic Review, March, pp. 80-102.

[14] Cole, H. and L. Ohanian. The Great Depression in the United States from a Neoclassical Perspective, Federal Reserve Bank of Minneapolis Quarterly Review, (Winter 1999) vol. 23 , no. 1 , p. 25-31.

[15] Cole, H. and L. Ohanian. 2000 "New Deal Policies and the Persistence of the Great Depression: A General Equilibrium Analysis", Discussion Paper, Federal Reserve Bank of Minneapolis.

[16] Eichengreen, Barry and Sachs, Jeffrey. "Exchange Rates and Economic Recovery in the 1930s". Journal of Economic History, December 1985, pp. 925-46.

[17] Fisher, Irving 1933. "The Debt Deflation Theory of the Great Depression," Econometrica 1: $337-35 \%$.

[18] Friedman, Milton and Schwartz, Anna. A Monetary History of the United States, 186\%1960. Princeton: Princeton University Press, 1963.

[19] Green, Susan and Charles Whiteman 1992. "A New Look at Old Evidence: On 'Nonmonetary Effects of Financial Crisis in the Propagation of the Great Depression'," University of Iowa, April.

[20] Hamilton, James. (1992) "Was the Deflation During the Great Depression Anticipated" Evidence from the Commodity Futures Market", American Economic Review, March, pp. $157-78$.

[21] Hanes, Christopher (1996) Changes in the Cyclical Behavior of Real Wage Rates, 18701990, Journal of Economic History 56, December 837-61. 
[22] Bureau of the Census, 1975, Historical Statistics of the United States, Washington D.C.

[23] Kiyotaki, Nobu, and Moore, John (1997) "Credit Cycles", Journal of Political Economy, $211-48$.

[24] Hoover, H. - The Memoirs of Herbert Hoover - 1929-1941 - MacMillan Co. 1952

[25] Kendrick, John W. 1961. Productivity trends in the United States. Princeton, N.J.: Princeton University Press.

[26] Lebergott, Stanley 1993 "Wage Rigidity in the Depression: Concept or Phrase?", Discussion Paper, Wesleyan University.

[27] Lamont, Robert (1930) "The White House Conferences", Journal of Business, vol III, no. 3, July, 269-71.

[28] Lucas, R. 1983. in Arjo Klammer ed. Conversations with Economists, Rowman and Allanheld Publishers.

[29] Lucas, R. and L. Rapping, Unemployment in the Great Depression: Is there a Full Explanation? JPE, 1972, vol 80, no. 1, 186-191.

[30] Margo, Robert 1993. "Employment and Unemployment in the 1930s", Journal of Economic Perspectives, Spring, 41-59.

[31] Murphy, Antoin E. "Money in an Economy without Banks: The Case of Ireland", pp. 41-50, The Manchester School of Economic and Social Studies.

[32] National Industrial Conference Board (1928) "Wages in the United States, 1914-1927", New York.

[33] O'Brien, Anthony (1989) "Behavioral Explanation for Nominal Wage Rigidity During the Great Depression" Quarterly Journal of Economics, November, 104, 719-35.

[34] Olney, Martha (1999) "Avoiding Default: The Role of Credit in the Consumption Collapse of 1930", Quarterly Journal of Economics, February, 319-335. 
[35] Romer, Christina D. 1988. "World War I and the Postwar Depression", Journal of Monetary Economics, 22, 91-115.

[36] Romer, Christina D. 1993. "The Nation in Depression", Journal of Economic Perspectives, Spring, 41-59.

[37] Survey of Current Business Supplement 1936, Department of Commerce, Washington, D.C..

[38] Temin, Peter (1989) Lessons from the Great Depression. 
Figure 1: Personal Income vs Suspensions by State during the Depression

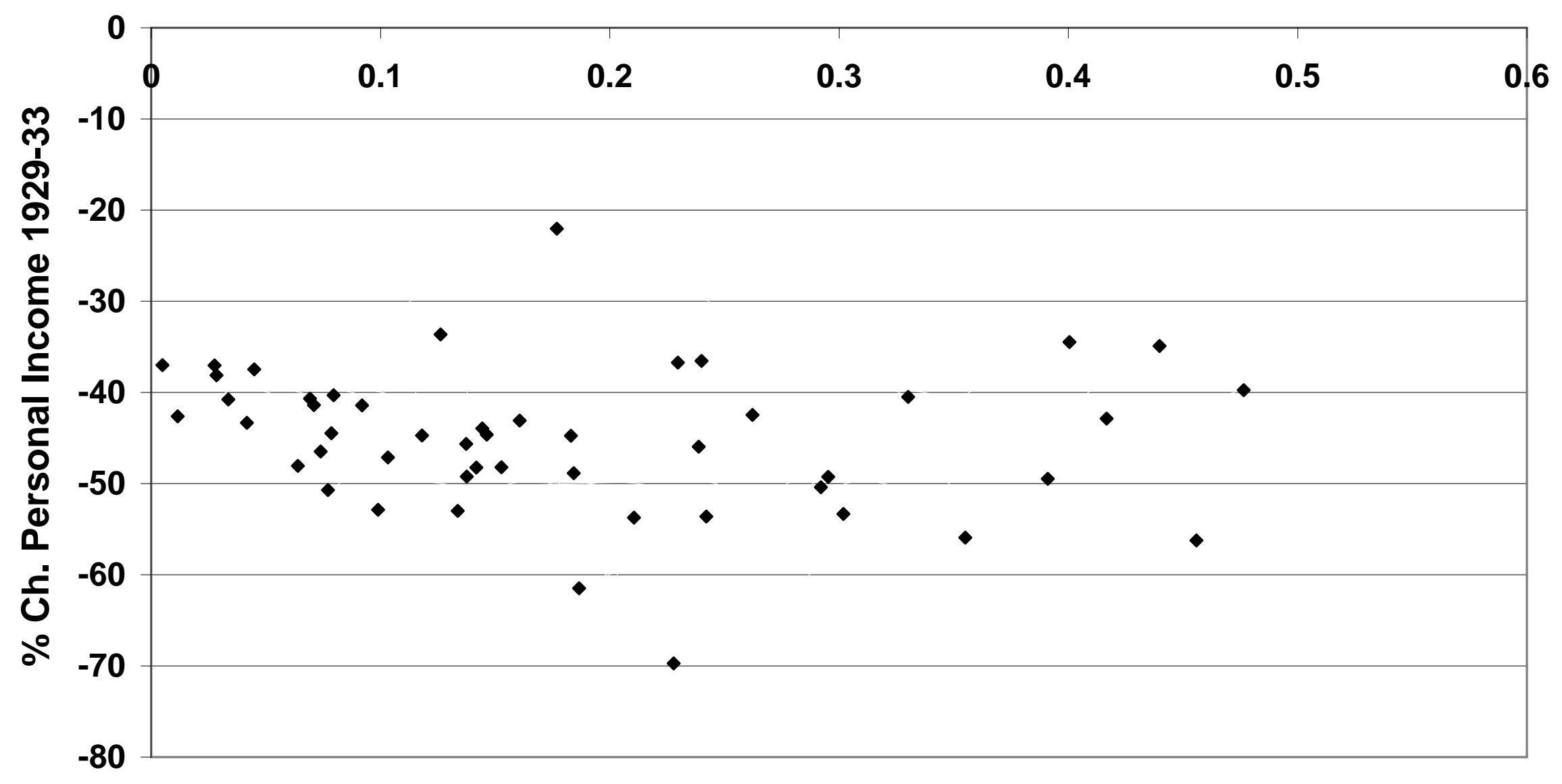

Commercial Bank Suspension 1929-33 / Total Deposits 1929 
Figure 2: Manufacturing Workers vs Bank Suspensions by State during the Depression

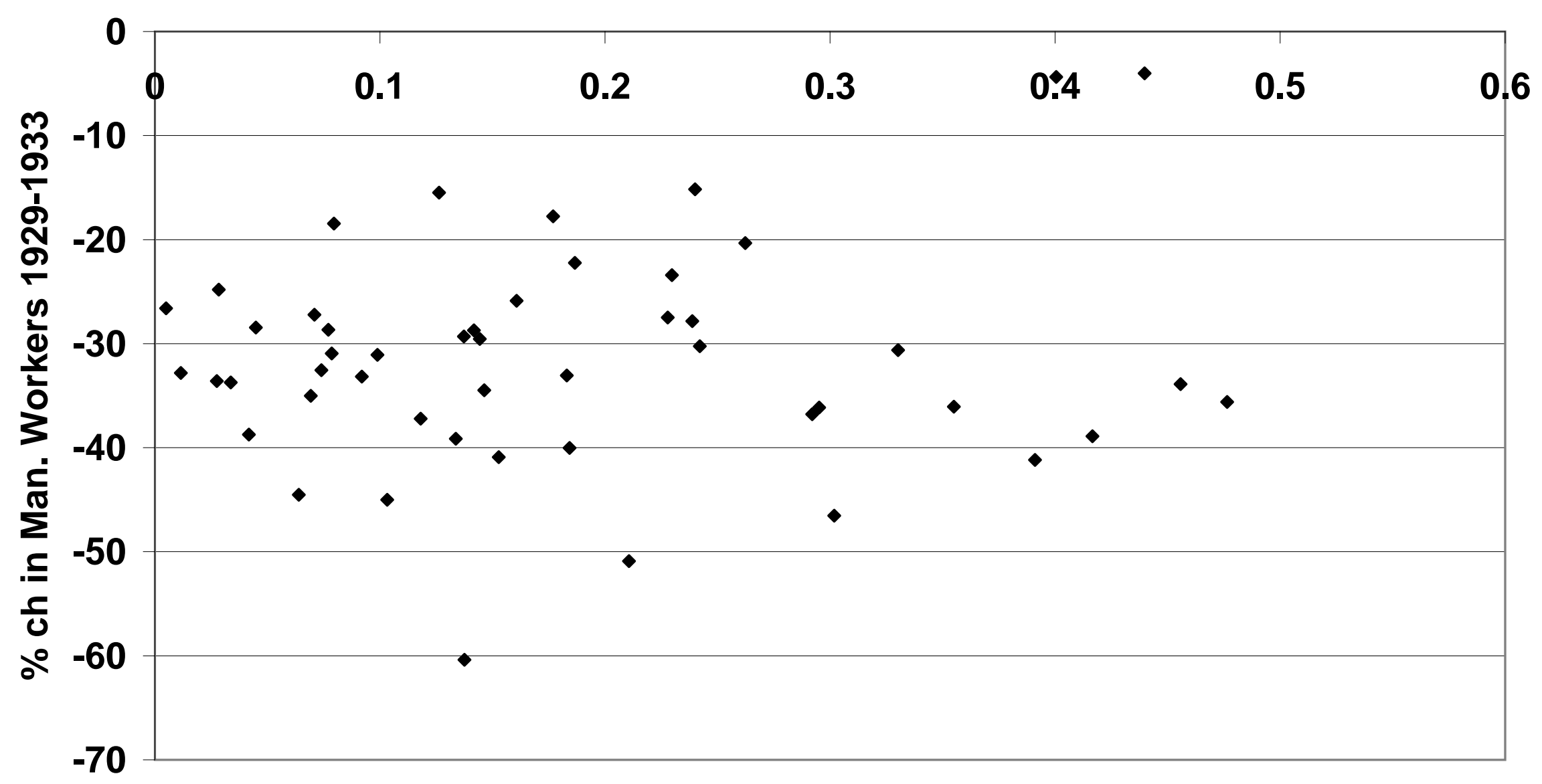

Commercial Bank Suspension 1929-33 / Total Deposits 1929 
Figure 3: Domestic Industries:

Profits, Dividends and Retained Earnings (without IVA)

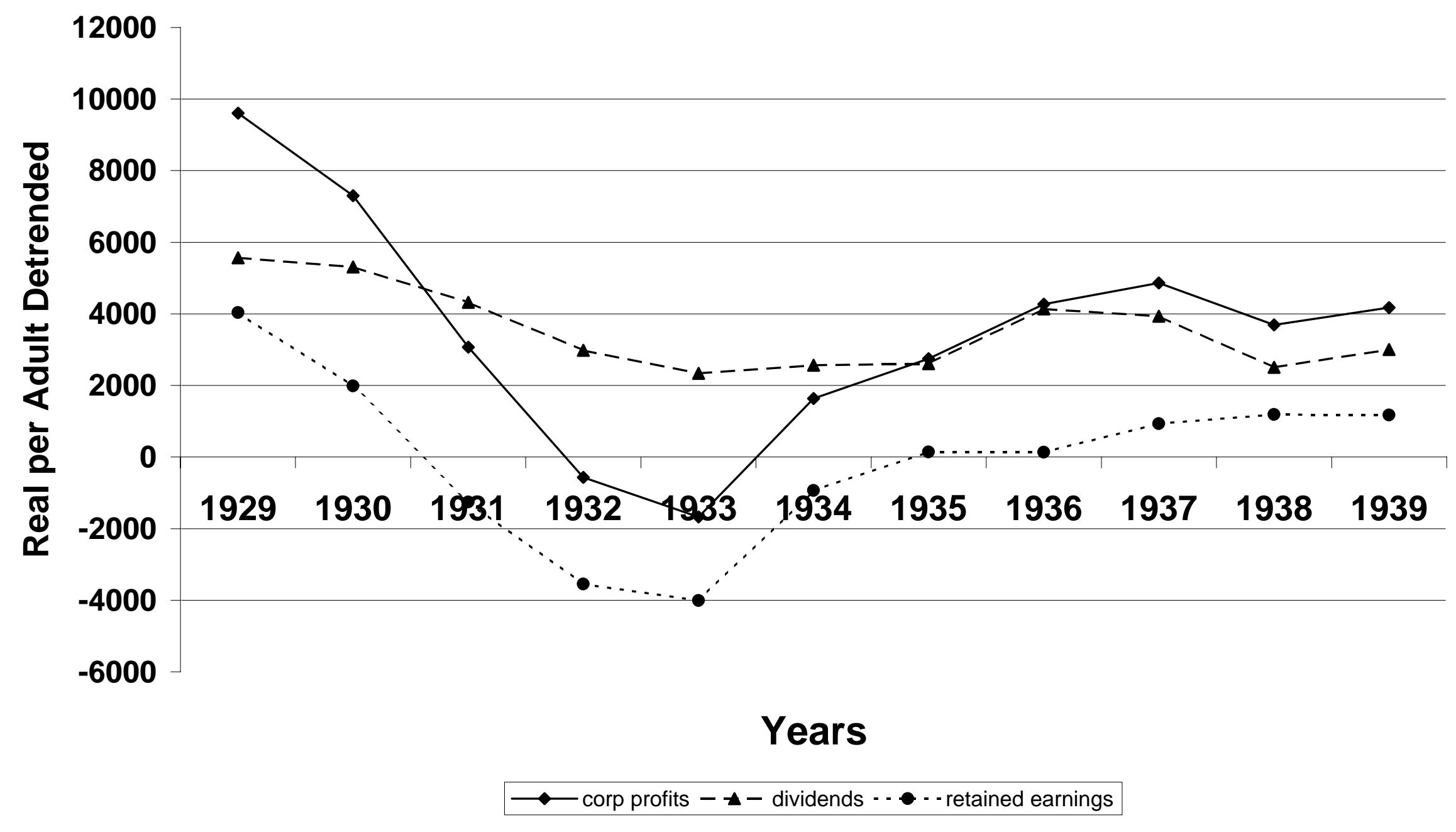


Figure 4: Manufacturing Industries:

Profits, Dividends and Retained Earnings (without IVA)

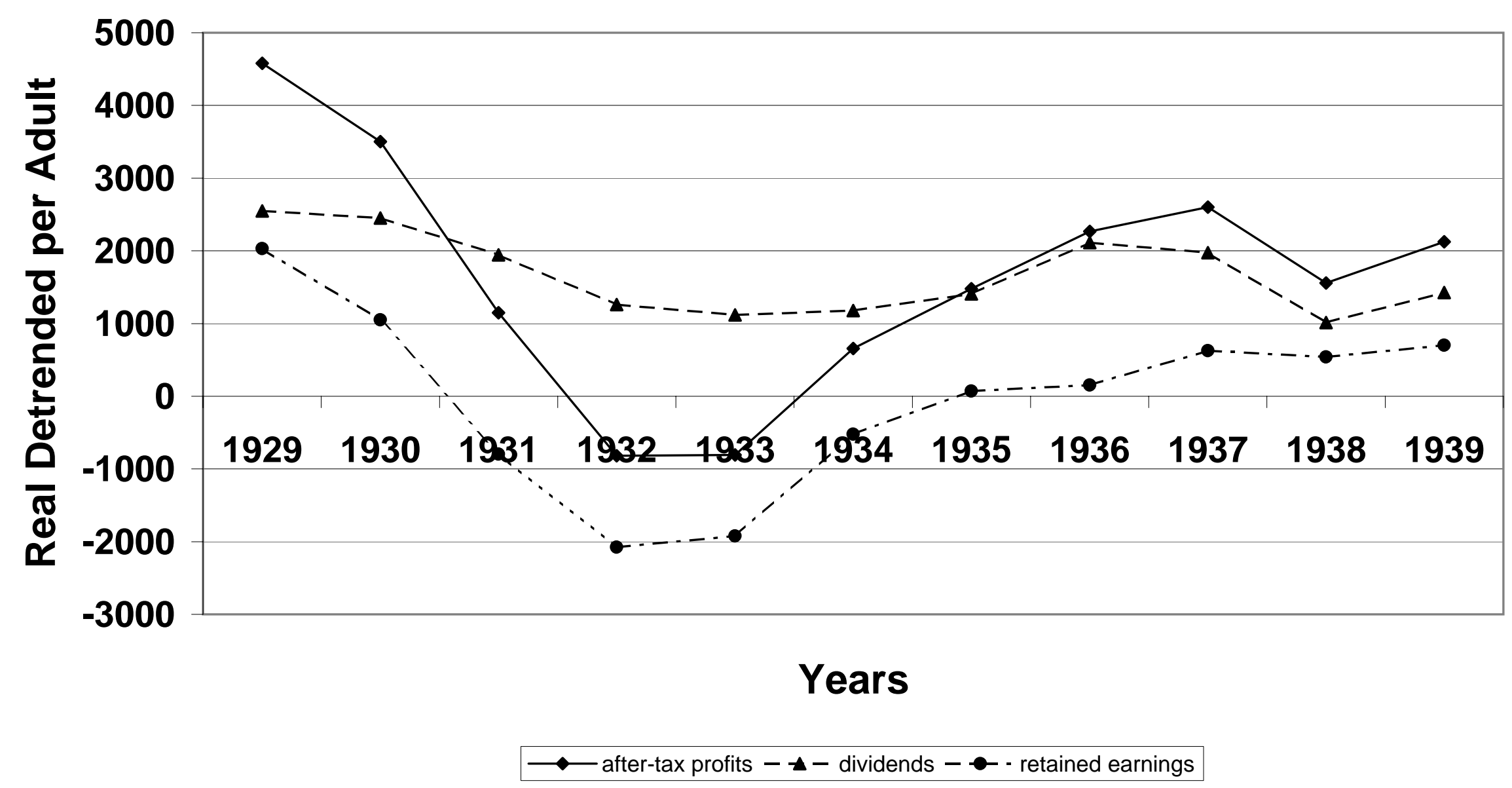

